\title{
Technological homogeneity within the Arabian Nubian Complex: Comparing chert and quartzite assemblages from central and southern Arabia
}

\author{
Yamandú H. Hilbert ${ }^{1}$, Rémy Crassard ${ }^{1}$, Jeffrey I. Rose ${ }^{2}$, Jeanne M. Geiling ${ }^{3}$, \\ Vitaly I. Usik ${ }^{4}$
}

1. CNRS, UMR 5133 'Archéorient’, Maison de l’Orient et de la Méditerranée, 7 rue Raulin, 69007 Lyon, France. Email: Hilbert: yamandu.hilbert@mom.fr; Crassard: remy.crassard@mom.fr

2. Ronin Institute, Montclair, NJ, U.S.A. Email: jeffrey.rose@ronininstitute.org

3.Instituto Internacional de Investigaciones Prehistóricas de Cantabria, Universidad de Cantabria, Santander,

Spain. Email: jeanmarie.geiling@unican.es

4. Archaeological Museum, Institute of Archaeology, National Academy of Sciences of Ukraine, Kiev, Ukraine.

Email: vitaly.i.usik@gmail.com

\begin{abstract}
:
Nubian Levallois technology is the defining characteristic of the Middle Paleolithic or Middle Stone Age technocomplex known as the Nubian Complex. Until recently, this technocomplex was found exclusively in northeastern Africa; however, archaeological surveys conducted across the Arabian Peninsula in the last decade have expanded the known distribution of this technological phenomenon. Since 2009, researchers from separate archaeological missions have mapped sites yielding Nubian cores and debitage, and by extension Nubian technology, in the southern, central and northernmost parts of the Arabia Peninsula. Nubian Complex artifacts in central and southern Arabia were made using different raw materials: in Al-Kharj (central Saudi Arabia) Middle Paleolithic industries were made exclusively on quartzite, while in Dhofar (southern Oman) chert was the only knappable material available for use. Given these differences, we sought to examine the influence of raw material variability on core morphology and size. Contrary to initial hypothesis, this study finds that the differences recorded are not a function of raw material properties. In both areas, Nubian cores were reduced using the same technological systems producing a set of preferential blanks. Rather, the recorded differences from raw material constrains were primarily due to knapping accidents, which occur in higher proportions at quartzite-based assemblages from Al-Kharj (specifically the siret fracture) compared with the chert assemblages from Dhofar. In sum, we argue that raw material had little effect on Nubian Levallois core technology and was not a constraint on Nubian Complex artisans.
\end{abstract}

Keywords: Nubian technology; raw material; Arabian Peninsula; Afro-Arabian Nubian Complex; Middle Paleolithic; Middle Stone Age

Published by the School of History, Classics and Archaeology, University of Edinburgh ISSN: 2055-0472. URL: http://journals.ed.ac.uk/lithicstudies/

This work is licensed under a Creative Commons Attribution 2.5 UK: Scotland License. 


\section{Introduction: Nubian technology and raw material variability in Arabia}

In recent years, research teams working across the Arabian Peninsula have made great advancements on the study of regional Middle Paleolithic human occupation (e.g., Amirkhanov 2006; Armitage et al. 2011; Bailey 2009; Crassard 2009; Delagnes et al. 2012; Petraglia et al. 2012; Rose \& Petraglia 2009; Rose et al. 2011). These data indicate that Middle Paleolithic industries found across the Peninsula present different typo-technological patterns that are comparable in a regional and interregional scale. Scholars have interpreted this variability as representative of different hominid or culture groups producing different lithic industries, who inhabited separate hunter-gatherer ranges within Arabia. These groups appear to have flourished during generally favorable climatic regimes throughout Marine Isotope Stage (MIS) 5, between 130-75 thousand years (ka) BP, and MIS 3, between 60-20 ka BP (Armitage et al. 2011; Delagnes et al. 2013; Petraglia 2011; Rose et al. 2011), while fluctuating landscape carrying capacity led to population expansions and overlapping huntergatherer ranges (Rose \& Marks 2014). Furthermore, these sites and lithic industries fill a gap in our understanding of the early expansions of anatomically modern humans (AMHs) out of Africa and the roll Arabia played as a facilitator, and at times inhibitor, for demographic expansions during this complex process. In this paper, we focus our attention on one specific Middle Paleolithic technocomplex known as the Nubian Complex (NC), by which we mean a group of technologically related industries that might share a common origin and occupy a discrete geographic and temporal range.

Isolated Nubian cores, Levallois points, diagnostic debitage, and workshop sites have been widely identified across the Arabian Peninsula. In other regions, Nubian cores have been reported from the southern Levant (e.g., Munday 1976; Boutié \& Rosen 1989; GoderGoldberg et al. 2016), across Northeast Africa (e.g., Chiotti et al. 2009; Olszewski et al. 2010; Van Peer \& Vermeersch 2000) and East Africa (e.g., Clark 1988; Kurashina 1978; Tryon \& Faith 2013; Yellen et al. 2005). Assemblages containing Nubian cores from northern India (Blinkhorn et al. 2015) and South Africa (Will et al. 2015) have recently been reported, doe to their isolated character incorporating them into the NC is problematic, further research need to be done. For the purpose of this paper we will concentrate on Nubian core technology found in Arabia (Figure 1), where sites have been located on the Nejd plateau and Rub' al Khali in southern Oman (Rose et al. 2011; Usik et al. 2013; Rose \& Hilbert 2014), across the Hadramawt plateau in central Yemen (Crassard 2009; Crassard \& Thiébaut 2011; Inizan \& Ortlieb 1987), in central Saudi Arabia (Crassard \& Hilbert 2013), and in the Al-Jawf region in northern Saudi Arabia (Hilbert et al. in press). Nubian Levallois technology was used by human groups living across these varied landscapes, which present different knappable materials indicating that NC toolmakers were flexible in respect to this resource. Across Arabia, different types of raw material have been detected, particularly in the Al-Jawf region of northern Saudi Arabia where complex tectonics and erosional factors have exposed a variety of knappable materials including quartz, quartzite, basalt, chert, and flint. Within the Middle Paleolithic findspots identified here, chert and flint were the most commonly used raw material for the production of Nubian points. Quartzite and quartz, while in some cases readily available, were seldom used, possibly hinting at raw material preferences (Hilbert et al. in press).

The objective of this study is to compare technological parameters of lithic assemblages from the Al-Kharj region, central Saudi Arabia, and Dhofar, southern Oman in order to identify variability within Nubian Levallois technology. Given that there is only one dated NC site in Arabia (Rose et al. 2011), our study is unable to control for temporal variability and any ensuing interpretation must take this into account. This analysis is restricted to comparing the technological parameters of core preparation and the production of preferential products 
made on chert and quartzite. We have chosen samples from Al-Kharj and Dhofar, given that these areas have widely differing raw materials, with little to no local variability. Artifacts from Dhofar were made exclusively on chert, while artifacts from Al-Kharj were manufactured entirely on quartzite. Consequently, we can rule out local preferences, meaning the active choice of one specific type of raw material over another, which might distort the selection of knappable material among the assemblages analyzed in this study, does not occur. Our hypothesis is that the Nubian cores from Al-Kharj will show comparable patterns in respect to the specific attributes presented by Usik et al. (2013) and different from the Nubian cores found in Dhofar. Whether these differences may be related to raw material used will be explored. To understand raw material variability and its effects on Middle Paleolithic human behavior is crucial for regional comparisons of lithic industries and therefor of importance to archaeologists working with stone tools, one of the most common artifacts found by archaeologists working in arid environments today.

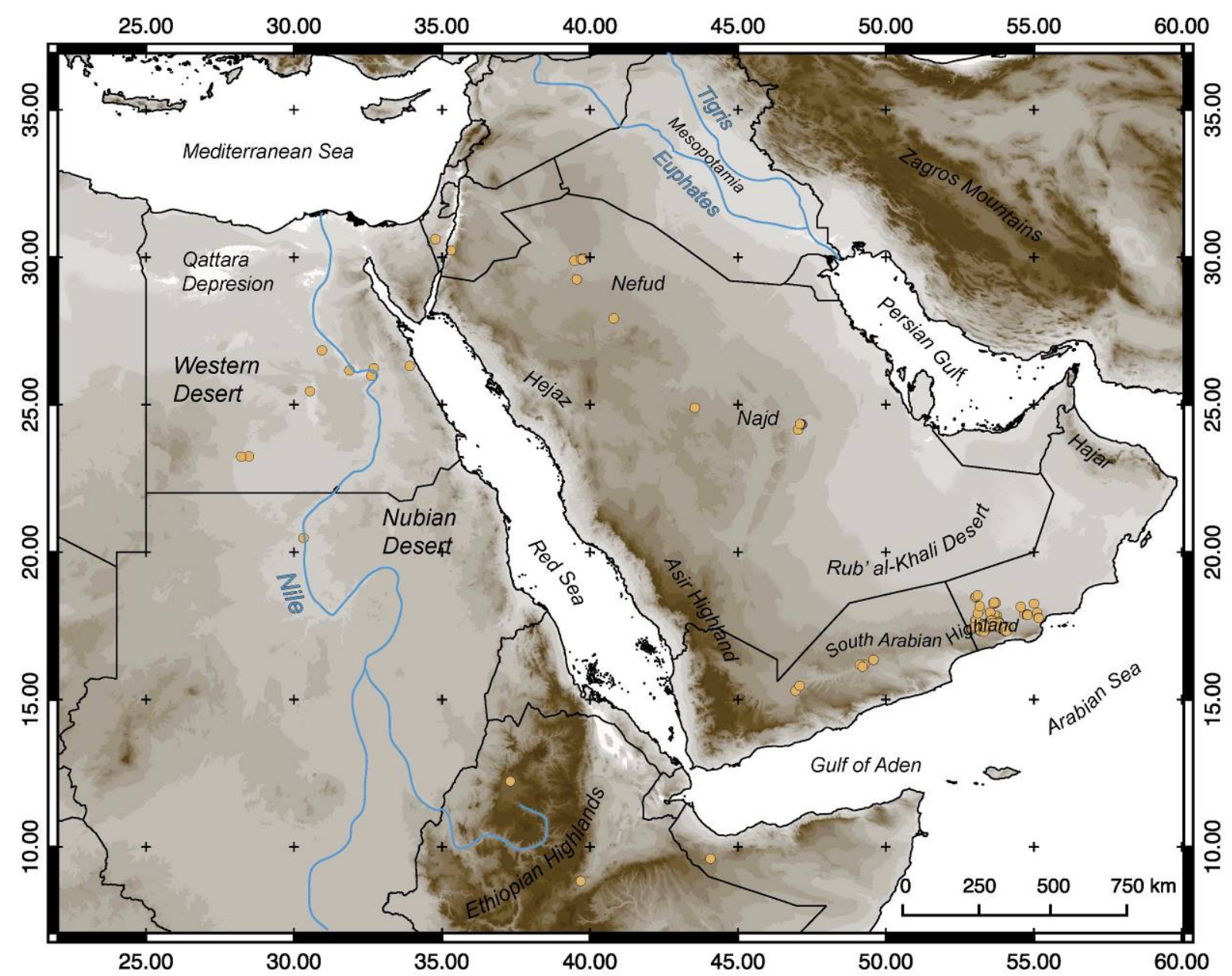

Figure 1. Map showing the location of Middle Paleolithic sites with Nubian cores in Northeast Africa and the Arabian Peninsula.

\subsection{Al-Kharj, central Saudi Arabia}

Since 2011, a joint French-Saudi archaeological mission, co-directed by J. Schiettecatte and A. al-Ghazzi, has been exploring the surroundings of the modern-day city of Al-Kharj, located approximately $100 \mathrm{~km}$ south of Riyadh (Schiettecatte et al. 2013; Crassard \& Hilbert 2013). The Al-Kharj area is characterized by plateaus, inselbergs, cuestas, plains and the presence of subsurface (and at times perennial surface) waters in the form of wadis and lakes. 
A succession of northwest oriented cuestas composed of Late Jurassic to Cretaceous formations with southwest facing scarps marks the northern part of the Riyadh province. Further south, the scarps are oriented towards the southwest. This change of orientation and the dip of the cuestas are caused by the Central Arabian Arch (Powers et al. 1966). At AlKharj, the north to south running scarps are cut by the convergence of the Central Arabian Graben system composed of the Nisah, Awsat, Bu'ayja' Ujman, Rufa and the Mugharah grabens. The paleo-wadis in the area are marked by the homocline of the Arabian Shelf and the central Arabian Graben System. Main fluvial structures in the region run from the Tuwayq Escarpment across the Tuwayq Plateau in a general west-east course. Towards the center of the survey area, the wadis follow the above mentioned graben structures such as Wadi Nisah and Wadi As-Sahba. Furthermore, small southward running wadis dissect the low Al-Urumah escarpment to the east of Al-Kharj (Vaslet et al. 1991).

A total of 47 Paleolithic sites have been identified thus far and range from Lower Paleolithic to Middle Paleolithic in age and cultural attribution. Middle Paleolithic sites with Nubian Levallois technology have been found exclusively along the Rufa Graben (Figure 2).

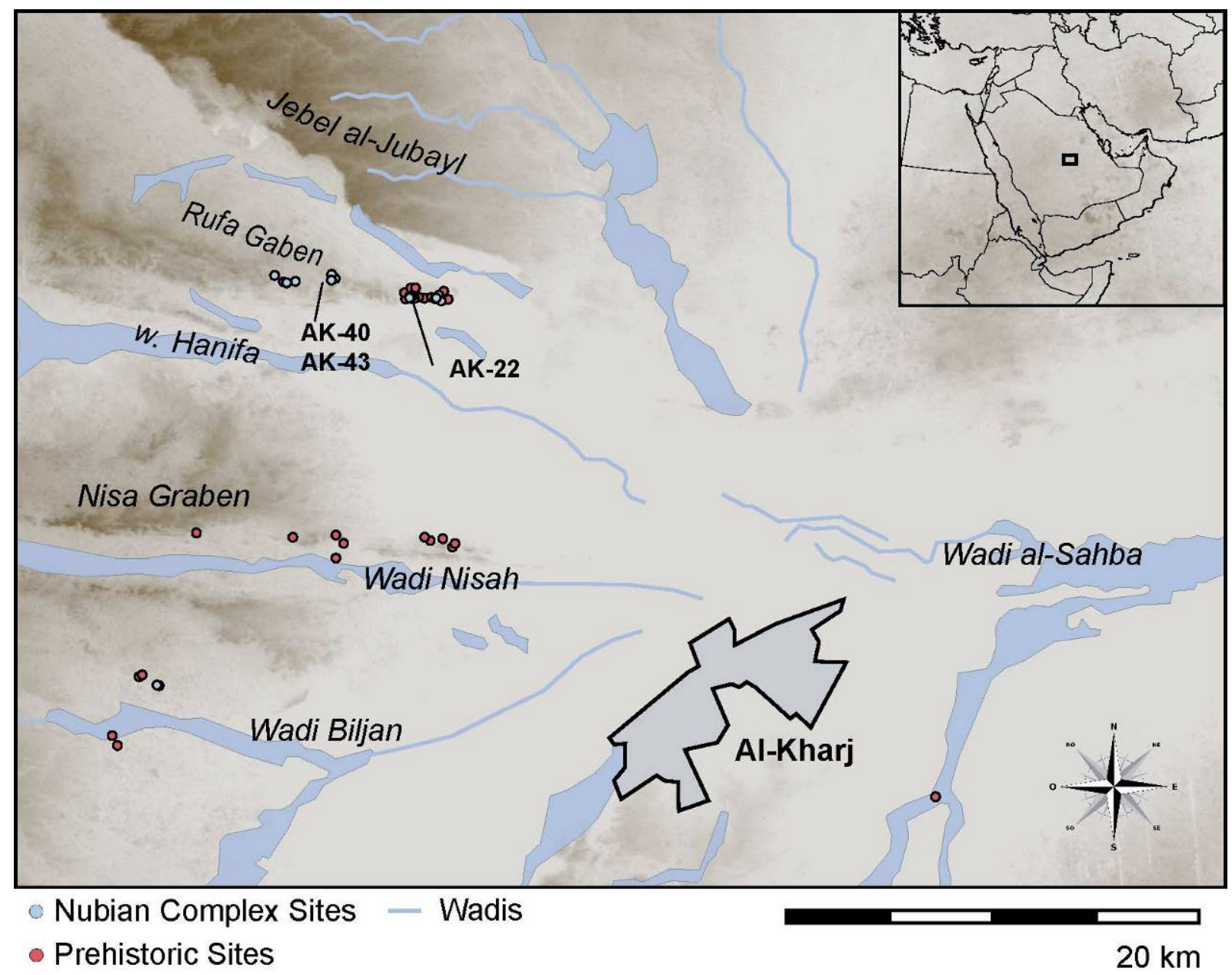

Figure 2. Map showing the location of the Rufa Graben and the Paleolithic sites with Nubian cores.

Approximately $30 \mathrm{~km}$ in length and between 0.8 and $1.5 \mathrm{~km}$ in width along its northsouth axis, the Rufa Graben is composed of three segments, respectively from West to East: the Ammaj segment, the Sha'al segment and the Ashqar Maraghah segment. The northern face of the graben is marked by the Jebel Umm Ash-Sha'al with its roughed cliff rising 80100 meter above the bottom of the graben. Beyond the cliff, this feature extends towards the Northeast as a flat undulating plateau composed of beige bioclastic, bioturbated limestone and 
clayey limestone (Sulaiy formation). The graben's southern face is, for the most part, masked by superficial deposits except for its eastern crest that is also composed of Sulaiy formation limestone. Survey activities along the Rufa Graben were undertaken close to the contact zone between the Sulaiy limestone and the Cretaceous Yamamah sandstone formations. Here, outcrops containing high quality, fine-grained quartzite and siltstones presenting a dark weathered cortex were observed (Figure 3); lithic scatters were found almost exclusively associated with these raw material sources.
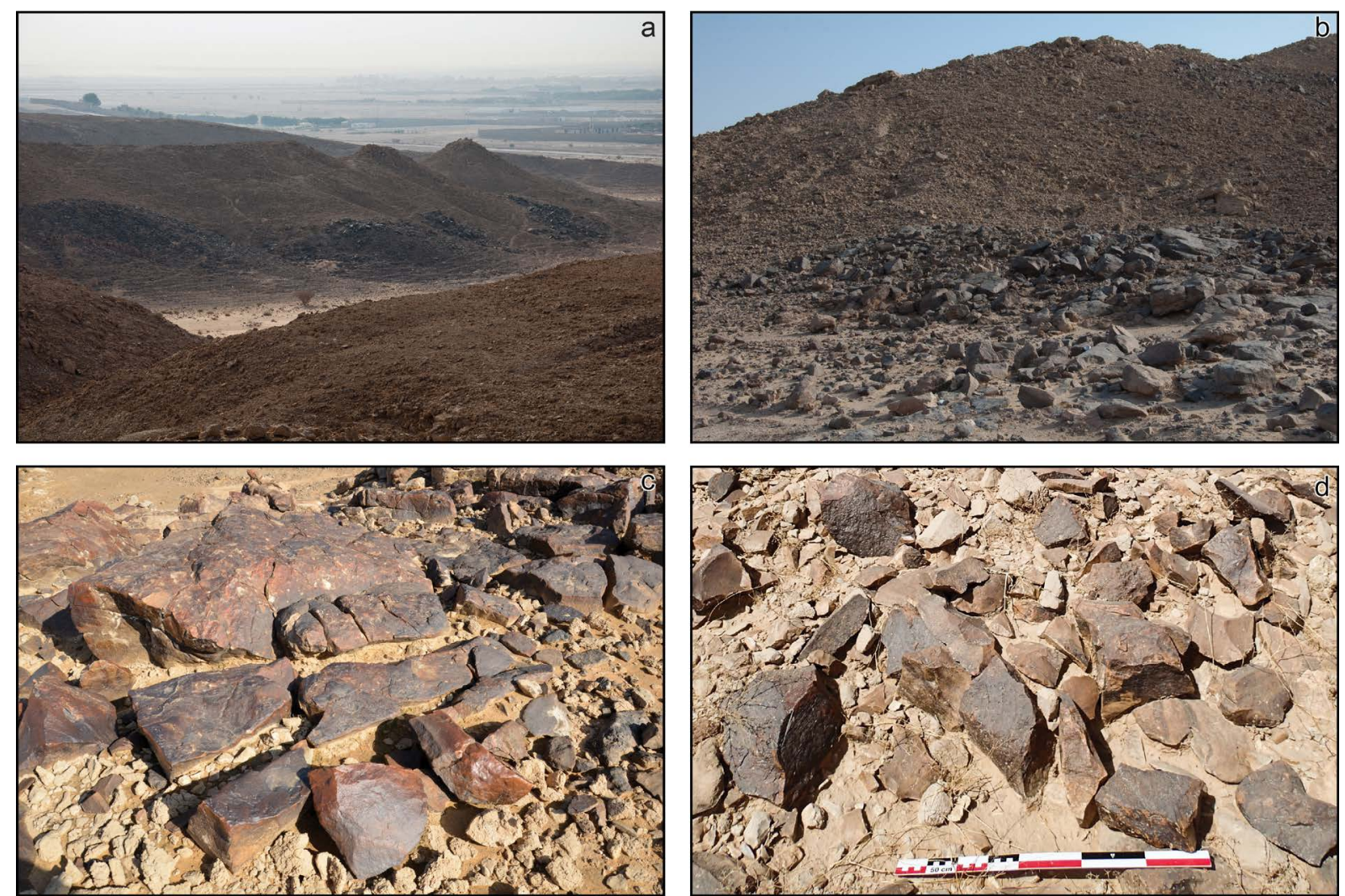

Figure 3. Quartzite outcrops along the Rufa Graben. a) Note the black weathered quartzite outcrops at the side of the jebel. b) Raw material outcrop at AK-43. c) The large block of quartzite in the forefront of the photograph measures approximately $50 \mathrm{~cm}$ in diameter. d) Raw material outcrop at AK-47.

\subsection{Dhofar, southern Oman}

Since 2009, the Governorate of Dhofar in southern Oman has been the subject of archaeological survey and excavations conducted by the Dhofar Archaeological Project (DAP). Dhofar covers an area of nearly 100,000 $\mathrm{km}^{2}$ and its landscapes are partitioned into six ecological zones (from South to North): 1) coastal plain; 2) summit grasslands; 3) seaward slopes and southern draining wadis; 4) northern face of the escarpment; 5) dry plateau; 6) and the interior desert (Zarins 2001; Rose et al. 2011). The vast majority of NC sites have been mapped north of the escarpment across the arid badlands known as the Nejd Plateau, which is described in greater detail below (Figure 4).

Tilting northwards from the Jebel Qara (also known as the Dhofar Mountains), the highlands flattens onto a deeply incised limestone plateau that extends approximately $250 \mathrm{~km}$ east-west and $150 \mathrm{~km}$ north-south. At its southern extent, along the interior flanks of Jebel Qara, the dry plateau is a barren scabland characterized by intricate minor wadis dissecting the plateau. Further towards the North, these smaller drainage systems converge into a series of large, deep parallel canyons, among the most prominent being Wadis Ghadun and Aydim. The Nejd catchment system debauches into the southern Rub' al Khali basin, where 
widespread relict lacustrine deposits indicate the presence of ancient playa lakes within this zone.

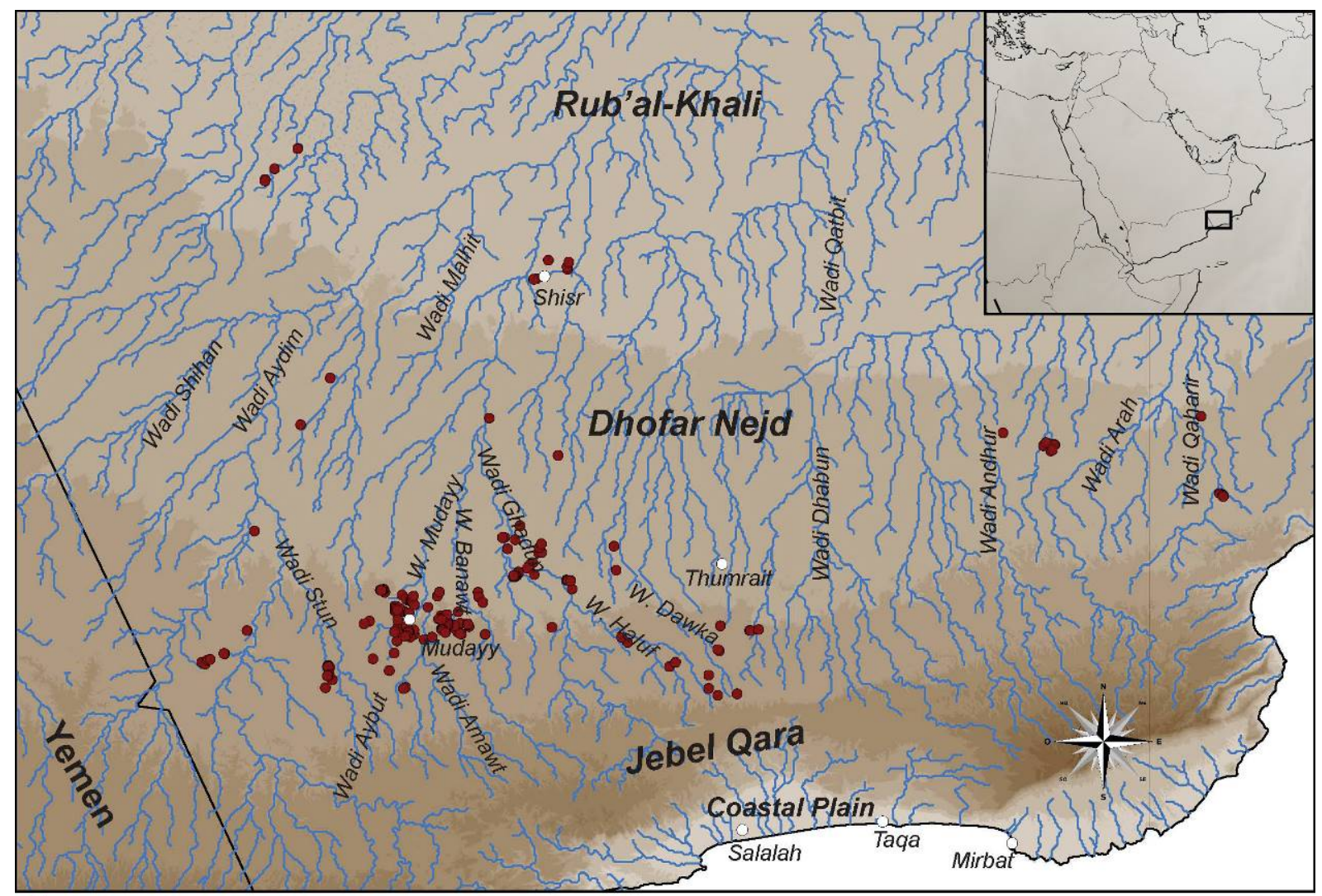

Nubian Sites in Dhofar

Figure 4. Map showing the Nubian Middle Paleolithic sites in Dhofar.

Three types of high-quality Eocene chert are found throughout the Nejd plateau (Figure 5). Mudayy chert, which outcrops from the Umm er Radhuma formation, is found mostly across the southern and central regions of the Nejd. This high quality material occurs in large banded slabs up to $40 \mathrm{~cm}$ in maximum diameter. Rus formation chert outcrops are found concentrated in the southern areas of the plateau, divided into the Aybut and Gahit members (Platel et al. 1991). Gahit is a high quality gray chert, often with banding and a thin cortex. Nodules and slabs of this type vary greatly in size, often measuring between 10 and $25 \mathrm{~cm}$ of maximum diameter. Aybut chert ranges widely in quality, outcropping as plaquettes within a chalky dolomitic matrix. Despite being extremely fine-grained, these plaquettes have often been geologically dislocated, causing interior fissures that diminish the quality of the Aybut member relative to Gahit and Mudayy cherts.

\section{Methods}

\subsection{Lithic analytical protocol}

Middle Paleolithic NC cores from Dhofar and Al-Kharj were analyzed using comparable technological classification systems (i.e. Rose et al. 2011; Crassard \& Hilbert 2013; Usik et al. 2013; Hilbert et al. in press). We employ the methodological framework proposed in Usik et al. (2013), which defines specific parameters for identifying variability within Nubian core technology. Within this scheme, Nubian Levallois cores are classified as Type 1, Type 2 or Type 1-2, describing the preparation of the core's dorsal working surface. The defining characteristic of the Nubian point production system is the creation of a median distal ridge 
(MDR) from an opposed secondary striking platform. Within the Nubian reduction sequence, we identify divergent or partially divergent preparation struck from the distal platform: this preparation is termed "lateral-distal" or "bilateral-distal". Likewise, in "bidirectional" or "bidirectional-lateral" organizational systems, removals originate from the distal platform. In these cases, the bidirectional preparation of the Levallois surface is achieved by combining distal-divergent and proximal-unidirectional removals; in other case, additional lateral or bilateral preparation is added (in these cases we classify the Levallois surface preparation as bidirectional-lateral).
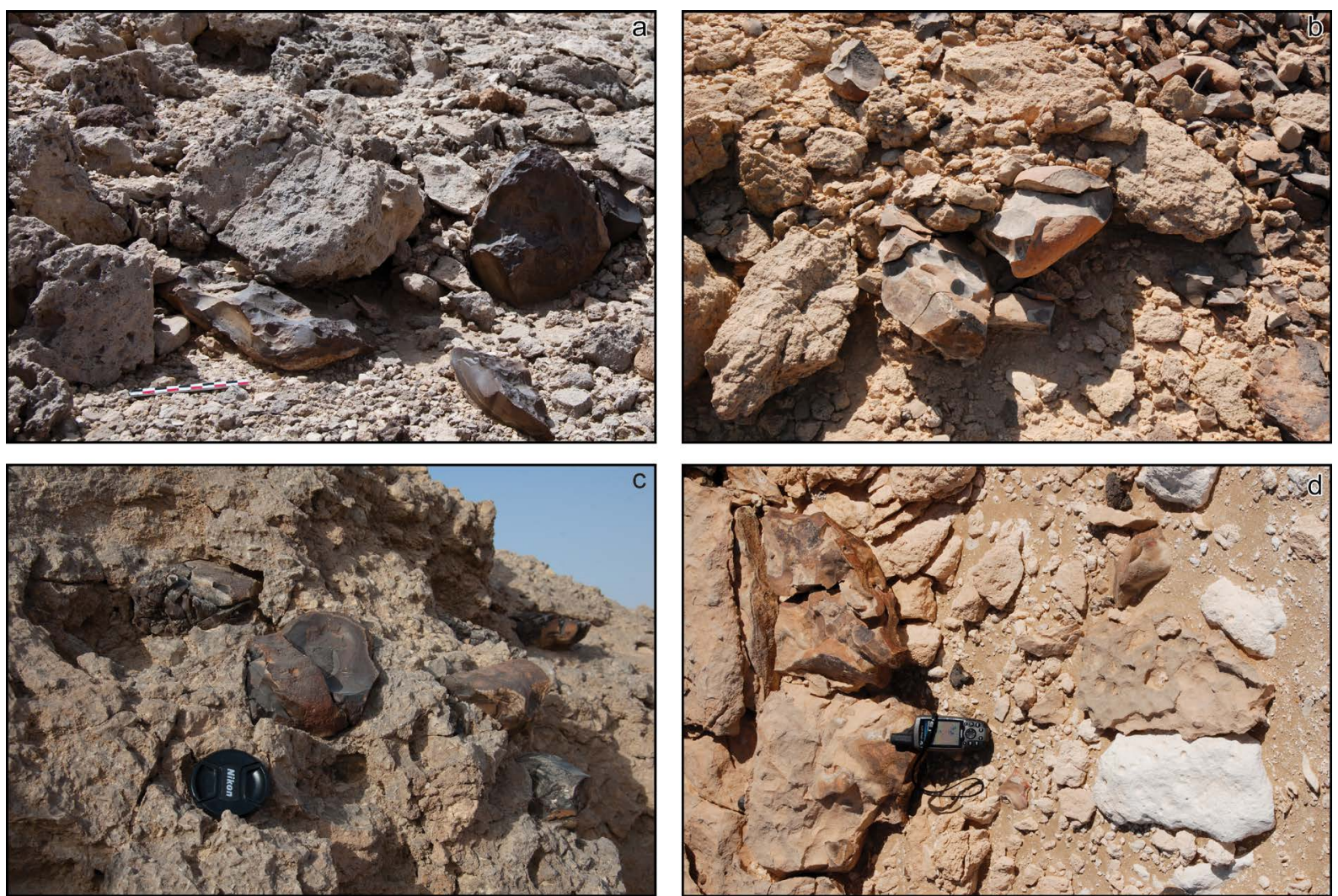

Figure 5. Chert nodules eroding from the plateau. a) Mudayy Chert outcrop at TH.383. b) Mudayy chert outcrop. c) Gahit Chert outcrop from the Wadi Haluf area. d) Chert outcrop from the Aybut area.

Often there are combinations of these patterns, particularly among Nubian Type 1 cores, of distal divergent and proximal convergent removals. Given the "combined" nature of the Nubian points or cores reduction sequence a strict delineation between the Nubian and the Levallois “constructed” reduction system (sensu Boëda et al. 1998), is problematic.

Nubian core shapes, on the other hand, shows a concise range from triangular to pitched to cordiform, depending on the configuration of the lateral edges of the cores. Given the importance of the MDR in preparing the Nubian Levallois working surface, MDR crosssections were recorded, as was the distal platform angle relative to the working surface (DPA. In addition to these morphological observations, core metric dimensions were recorded for quantitative comparisons. These metric data include length, midpoint width, thickness and volume of the Nubian cores, as well as their Index of Core Elongation (ICE) and Index of Core Flattening (ICF). ICE is determined by dividing the core length by its midpoint width; a value equal or greater than two indicates that the core is twice as long as it is wide. ICF is a result of the division of the cores midpoint width by its thickness. The larger this number, the wider and flatter the core. Our analysis uses these qualitative and quantitative data to explore technological variability between Al-Kharj and Dhofar NC core assemblages. Given that each 
of these samples is made on different raw materials, Dhofar cores made on chert and Al-Kharj cores made on quartzite, we will explore if observed differences are a function of raw material type.

\subsection{Knappable materials and knapping fractures}

While rocks in general are classified as either being of sedimentary, metamorphic or volcanic origin, knappable materials used in prehistory can be divided into several groups, including three main categories: a) crystalline, to which quartz and rock crystals belong; b) cryptocrystalline, most common are chalcedony, jasper, radiolarites, flint and chert; c) and amorphous, encompassing quartzites (e.g., Hahn 1991; Müller \& Warth 1985). These vary in terms of quality, hardness and availability. Most knappable raw materials are composed of grains that are rearranged into scales (Michelsen 1966; Rotlländer 1989); the disposition of the grains and scales varies greatly, influencing its quality, as does the inclusions (e.g., microfossils found predominantly in chert). In this study we focus on chert and quartzite, using Luedke's general definition of chert as one category of silica based mineral with cryptocrystalline properties (Luedke 1992: 5-6), which includes flint, agate, chalcedony and jasper. Each of the different materials within this group shows a distinct structure in respect to their grains and scales. According to Rottländer (1989) these are divided into variants with better developed scales due to the symmetry of the grains, and variants where the grains are coarser, negatively influencing the structure of the scales.

Important for the use as knappable raw material is the level of crystallization. Quartzite has a coarse to fine grained conglomeratic structure with strongly intergrown and interfingering crystallites (also called grains). Homogenous forms have an opal-based matrix, which at times is crystalized into chalcedony. The knappable properties of quartzite are variable, depending on the quality of the raw material. Fracture surfaces are usually rough showing a grainy or sugary texture (Whittaker 1994). A specific mineral aspect of quartzite is that fracturing does not cause the break to go around the grains (as it does with sandstone), rather, the fracture passes through the grains (Best 1982) and does not negatively influence its knapping properties. The quartzite from Al-Kharj is hard and somewhat variable when it comes to its degree of coarseness. Some outcrops may produce blocks of outstanding quality, while others yield more coarsely grained material with poor crystallization that requires additional effort to process.

Chert is determined by the crystallization of its structure, which tends to be stronger towards the center of the nodule and harder to knap (Hahn 1991). In general, however, the impact force that travels through the rock when it is hit with a percussor, bounces back from the inner and outer layers of the nodule, causing conchoidal breakage. The chert from Dhofar is very homogenous, with little to no variability when found in primary position. Chert nodules that have been exposed to the elements for some time, however, are considerably more brittle and tend to shatter.

It must be said in advance that the majority of knappable materials are susceptible, some more than others, to fracturing due to structural weaknesses of the raw material and knapping mistakes. Hinge fracturing is common among most materials and occurs when the impact force that is supposed to detach a flake or any other type of debitage dissipates towards the outer flaking surface on the core, thus reducing the distal (downward) trend causing a sharp drop in breakage velocity. This break causes a rounded (hinge-fracture), sometimes stepped (step-fracture) termination on the debitage and a sharp step or hollow negative on the core. In general the factors influencing the occurrence of hinge fractures are: 1) the force applied during percussion is insufficient; 2) hinging occurs regularly due to inappropriate Levallois surface preparation, resulting in a flat surface; 3) striking platform angle is too close to $90^{\circ}$ 
(Dibble \& Whittaker 1981; Whittaker 1994); and 4) the gesture during knapping, for instance when the blow is not tangential enough. Overpassing occurs when the force used to detach the flake from the core is too high, essentially the opposite of a hinge fracture. The result, in the case of an overpassed Nubian point, is an elongated removal that overshoots the length of the core and removes the core's distal platform. The siret fracture (accident siret) refers to the breakage of a flake in two parts along the longitudinal axis from the point of impact. It can occur by using any kind of knapping technique (hard and soft hammer direct percussion, but also indirect percussion and pressure) (Inizan et al. 1995). This type of fracture is particularly common when using a coarse-grained raw material, like quartzite. Siret fractures are a knapping accident, rather than a mistake like plunging (overpassed) and hinging fractures. The siret fracture is a result of the raw materials texture and quality, and much less of the artisan's ability, or lack thereof.

\section{Materials}

Six assemblages were included in this study: three from Dhofar and three from Al-Kharj. The assemblages from Dhofar are TH.383, TH.69 and TH.377, previously described in Rose et al. (2011) and Usik et al. (2013). While TH.383 and TH.377 are located directly on a Mudayy chert outcrop, TH.69 is located approximately two kilometers away from the nearest chert exposure. From Al-Kharj, the sites AK-22, AK-40 and AK-43 have been chosen. While both AK-22 and AK-43 are directly on quartzite outcrops, AK-40 is located on top of a jebel with no discernible raw material source nearby. All samples come from systematic or targeted collections of surface sites. In systematic collections, a sampling area is designated and all artifacts in this area collected and analyzed. This was done for all Dhofar sites, AK-40 and AK-43. At AK-22, targeted collections of cores (Levallois and non-Levallois) and technologically diagnostic were made. Here we describe and compare Nubian cores from AlKharj and Dhofar to explore variability in raw material usage. The overall composition of the assemblages has no bearing our study, as this analysis explores variability within a single Levallois method (i.e. Nubian).

\subsection{Al-Kharj samples}

Site AK-43 is located on the foot of a jebel in the western part of the Rufa graben. To the west of the site, the Rufa graben is cut by a tectonic fault through which a wadi meanders, creating a series of low and eroded terraces. The site's most prominent feature is a large quartzite outcrop; located at the foot of the jebel. Middle Paleolithic artifacts are concentrated on the slope just below the quartzite outcrop. A total of 260 artifacts were collected, of which 146 are cores. Artifact density is high, with approximately 10 artifacts per square meter. The main technological system used to reduce the Middle Paleolithic cores is the Levallois method. AK-40 is located approximately 260 meter to the northeast of AK-43. The surface of the site is moderately flat and artifacts were found on a saddle atop the jebel. Artifacts including quartzite cores and debitage, were diffuse and low in density. As such, all visible artifacts were collected. No raw material outcrop was detected at AK-40 or in its immediate vicinity. The presence of both cores and debitage, as well as refits, indicates that knapping took place at the site despite the steep climb up the jebel (if the large outcrop at AK-43 is considered as source for the raw material). A total of 112 artifacts were collected and analyzed. Of these, 84 are cores, the majority of which are classified as Levallois.

The combined samples from AK-22, AK-40 and AK-43 total 548 artifacts (Table 1). As stated above, most of the cores found at the sites were reduced using a preferential Levallois reduction strategy; the non-Nubian Levallois preferential cores have been prepared with 
bidirectional or bidirectional lateral preparations, while centripetal and unidirectionalconvergent variations are rare.

Table 1. Artifact counts from AK-22, AK-40 and AK-43.

\begin{tabular}{lccc}
\hline Artifact Type & AK-22 & AK-40 & AK-43 \\
\hline Non-Levallois cores & $\mathbf{3 2}$ & $\mathbf{7}$ & $\mathbf{2 0}$ \\
\hline Single Platform Blades Core & 0 & 0 & 2 \\
Single Platform Flakes Core & 7 & 1 & 1 \\
2 Debitage Surfaces Core & 1 & 0 & 0 \\
Bidirectional Crossed Core & 1 & 1 & 1 \\
Bidirectional Opposed Core & 5 & 2 & 7 \\
Core Early Stage & 18 & 3 & 9 \\
\hline Levallois cores & $\mathbf{9 0}$ & $\mathbf{7 7}$ & $\mathbf{1 2 6}$ \\
\hline Levalois Preferential Core & 65 & 21 & 29 \\
Levallois Preferential Point Core & 1 & 3 & 6 \\
Levallois Centripetal Recurrent Core & 7 & 1 & 10 \\
Nubian Type 1 Core & 4 & 9 & 18 \\
Nubian Type 2 Core & 5 & 17 & 19 \\
Nubian Type 1-2 Core & 8 & 2 & 21 \\
Early Stage Levallois & 0 & 24 & 23 \\
\hline Debitage & $\mathbf{5 4}$ & $\mathbf{2 8}$ & $\mathbf{1 1 4}$ \\
\hline Flake & 15 & 14 & 94 \\
Blade & 0 & 0 & 5 \\
Cortical Debordant & 6 & 0 & 1 \\
Debordant Element & 1 & 4 & 2 \\
Levallois Preferential Flake & 4 & 6 & 4 \\
Levallois Debordant & 5 & 0 & 0 \\
Levallois Flake & $\mathbf{1 7 6}$ & $\mathbf{1 1 2}$ & $\mathbf{2 6 0}$ \\
Nubian Levallois Point & 0 & 1 & 5 \\
\hline Total & & & \\
\hline
\end{tabular}

Nubian Type 1, 2 and 1-2 are present in different proportions among the three assemblages. At AK-43 (Figure 6), for instance, all three preparation types are present in somewhat equal numbers, while at AK-40, Type 2 prepared cores are more numerous (Figure 7). At AK-22, Type 1-2 prepared cores are more abundant. Core shape variability within the Al-Kharj samples is low, $45 \%$ of the Nubian cores from the three sites have triangular shapes, while pitched and cordiform cores occur at $28 \%$ and $27 \%$ respectively (Table 2). Internal assemblage variability increases when we look at the orientation of the preparation removals on the Levallois surface (Table 3). Bidirectional and bidirectional lateral preparations occur in greater numbers than other kinds of preparation (50\%). Bilateral distal and lateral distal are also common ways of preparing the Nubian cores (39\%), while bilateral, distal and centripetal preparation types occur in only $11 \%$ of the samples. The configuration of the distal portion of the Nubian cores from Al-Kharj also shows some variability. MDR cross-sections for both AK-22 and AK-43 are predominantly semi-steep, while AK-40 Nubian cores are steep (Table 4). DPA on the samples from Al-Kharj show a tendency towards semi acute angles. AK-40 
and AK-43 samples have few Nubian cores with acute distal angles; while at AK-22 this category is the second most common (Table 4).
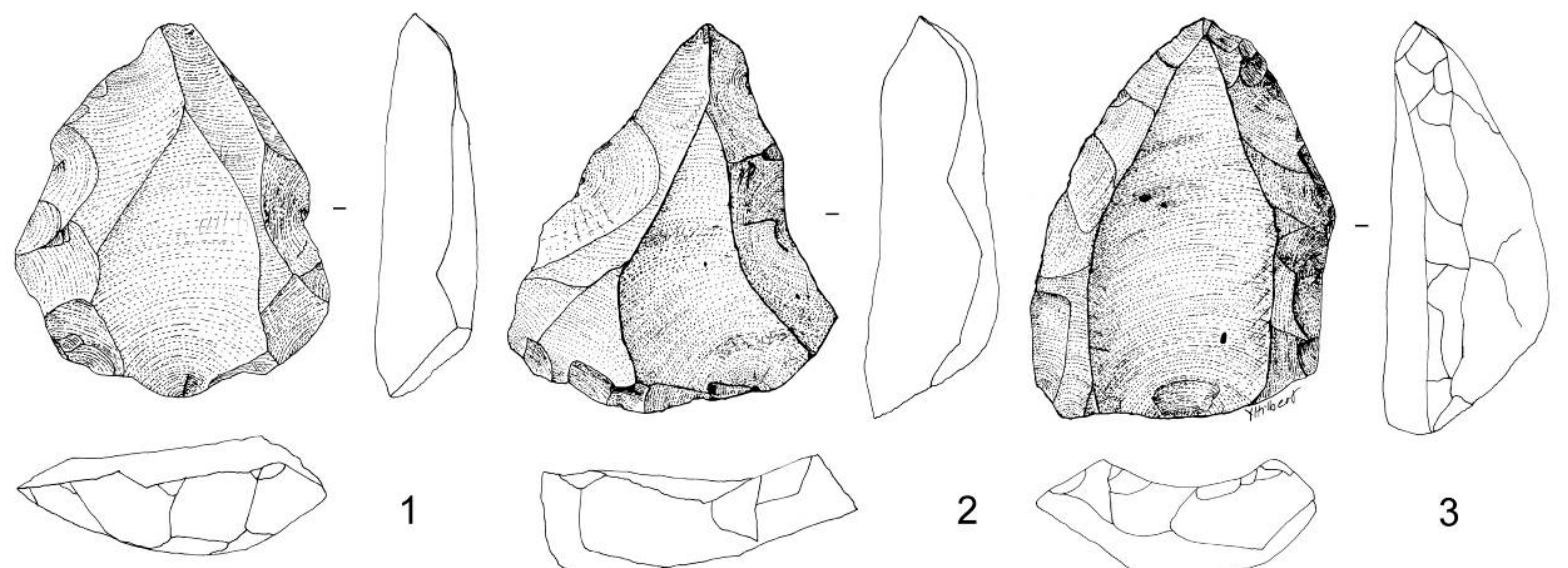

1

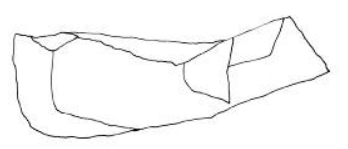

2
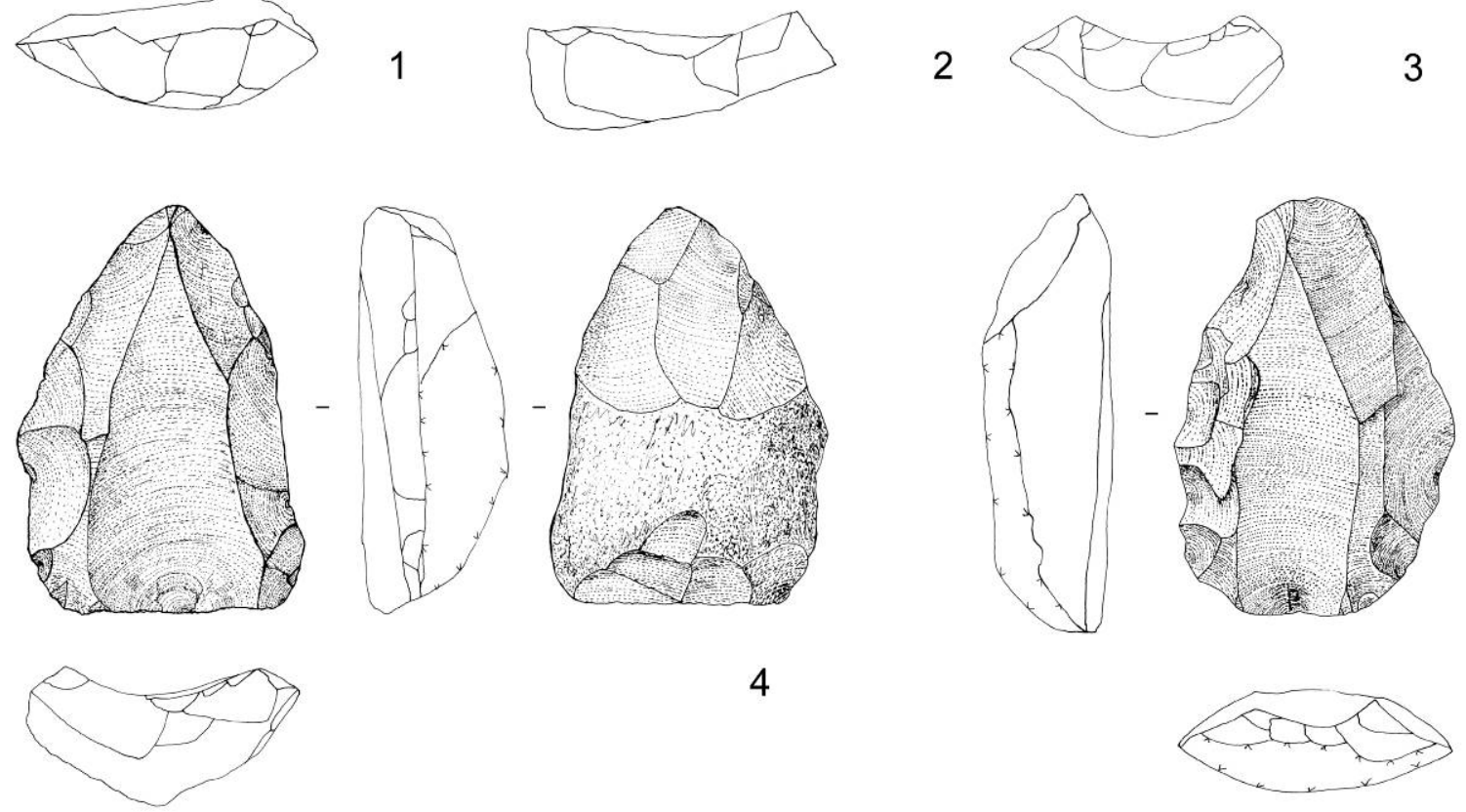

4
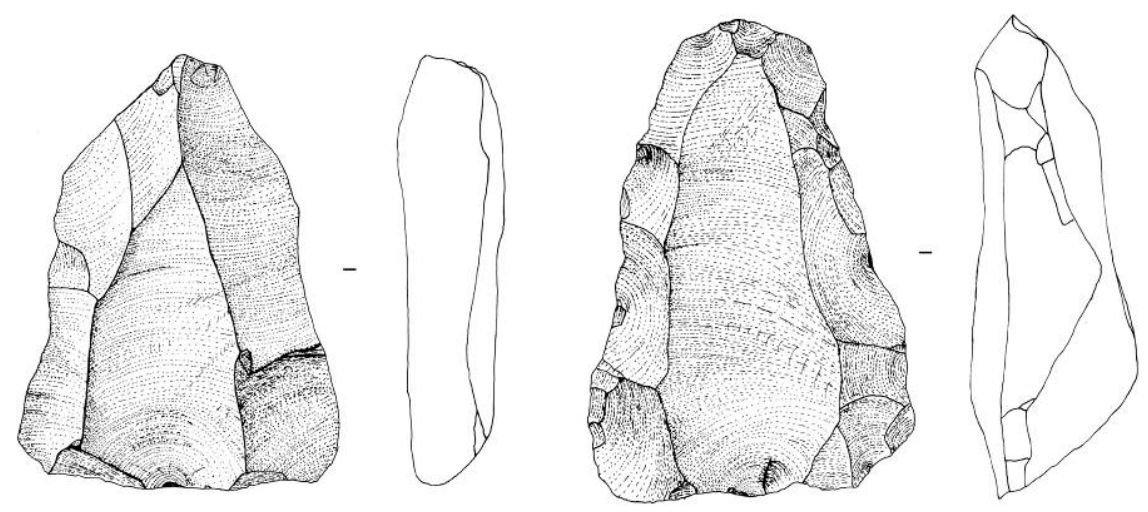

6
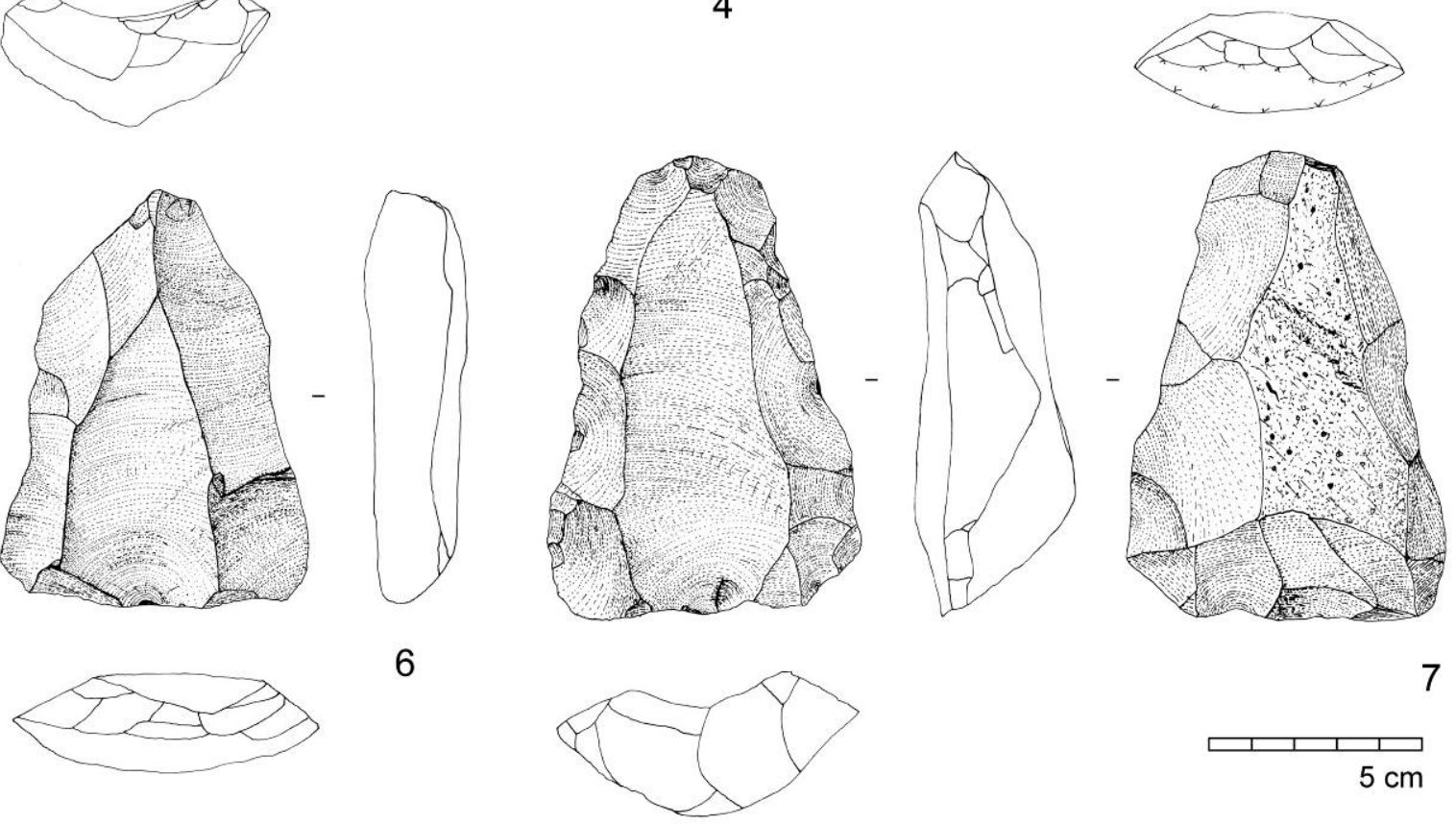

Figure 6. Nubian cores from AK-43. 1: cordiform core with Type 1 Nubian preparation; 2: triangular core with Type 1-2 Nubian preparation; 3: cordiform core with Type 2 Nubian preparation; 4: cordiform core with Type 1 Nubian preparation; 5: pitched core with Type 1-2 Nubian preparation; 6: pitched core with Type 1-2 Nubian preparation; 7: cordiform core with Type 2 Nubian preparation. 

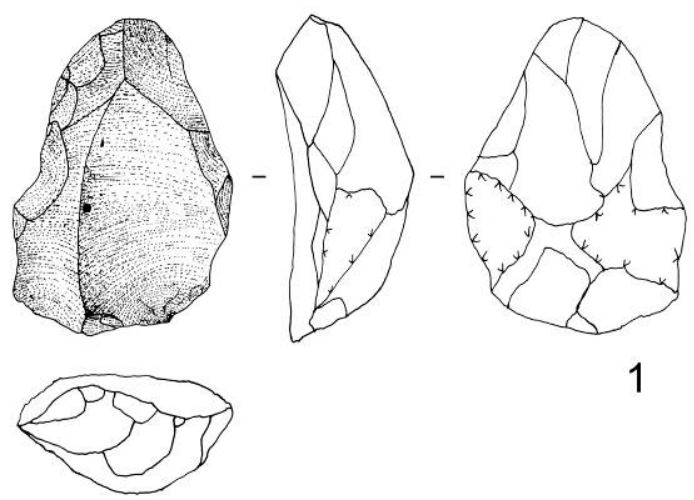

1
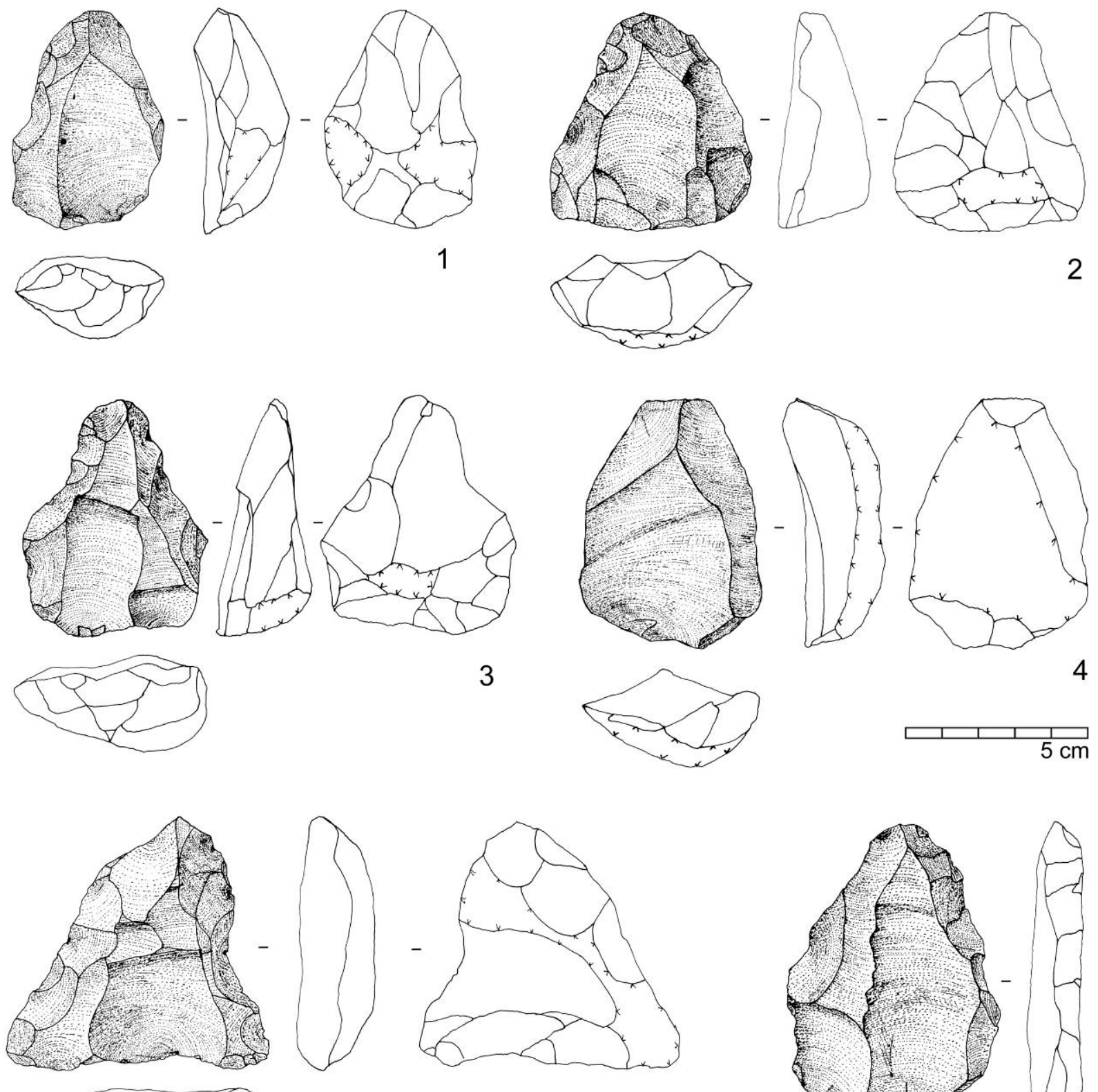

5
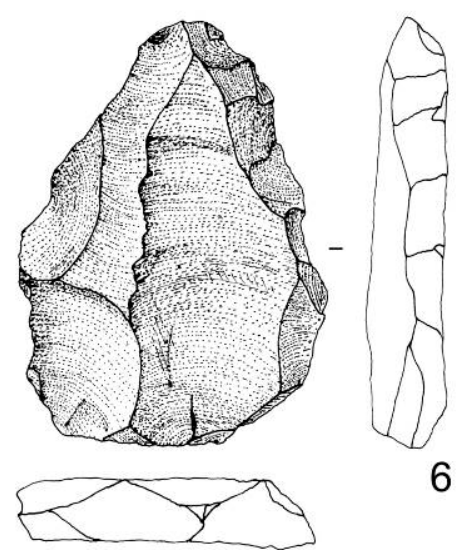

Figure 7. Nubian cores from AK-40. 1: cordiform core with Type 1-2 Nubian preparation; 2: cordiform core with Type 2 Nubian preparation; 3: pitched core with Type 2 Nubian preparation; 4: cordiform core with Type 1 Nubian core; 5: triangular core with Type 2 Nubian preparation; 6: triangular core with Type 1-2 Nubian preparation. 
Table 2. Al-Kharj samples core shape.

\begin{tabular}{lccccc}
\hline Site & Method & Triangular & Pitched & Cordiform & Total \\
\hline AK-22 & Nubian Type 1 & $1(25 \%)$ & $1(25 \%)$ & $2(50 \%)$ & $4(100 \%)$ \\
& Nubian Type 2 & $3(60 \%)$ & $1(20 \%)$ & $1(20 \%)$ & $5100 \%)$ \\
& Nubian Type 1-2 & $4(50 \%)$ & $2(25 \%)$ & $2(25 \%)$ & $8(100 \%)$ \\
AK-40 & Nubian Type 1 & $6(75 \%)$ & $1(12,5 \%)$ & $1(12,5 \%)$ & $8(100 \%)$ \\
& Nubian Type 2 & $9(56 \%)$ & $1(6 \%)$ & $6(38 \%)$ & $16(100 \%)$ \\
& Nubian Type 1-2 & $1(50 \%)$ & 0 & $1(50 \%)$ & $2(100 \%)$ \\
AK-43 & Nubian Type 1 & $5(28)$ & $9(50 \%)$ & $4(22 \%)$ & $18(100 \%)$ \\
& Nubian Type 2 & $10(53 \%)$ & $6(31)$ & $3(16 \%)$ & $19(100 \%)$ \\
& Nubian Type 1-2 & $\mathbf{7 ( 3 3 , 3 \% )}$ & $7(33,3 \%)$ & $7(33,3 \%)$ & $21(100 \%)$ \\
\hline Total & \multicolumn{5}{c}{$\mathbf{4 6}$} \\
\hline \multicolumn{7}{c}{$\mathbf{2 7}$} \\
\hline
\end{tabular}

Table 3. Al-Kharj samples Levallois surface preparation.

\begin{tabular}{|c|c|c|c|c|c|c|c|c|c|}
\hline$\stackrel{ \pm}{n}$ & 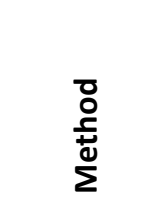 & 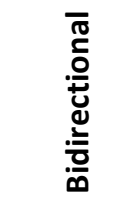 & 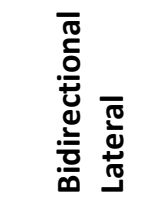 & $\begin{array}{l}\overline{\frac{\pi}{\pi}} \\
\frac{\pi}{\pi} \\
\frac{\pi}{\overline{0}}\end{array}$ & 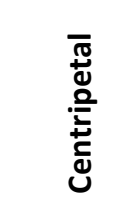 & $\begin{array}{l}\overline{\mathrm{J}} \\
\stackrel{\mathrm{n}}{\mathrm{D}}\end{array}$ & 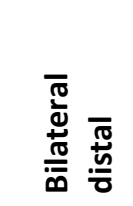 & 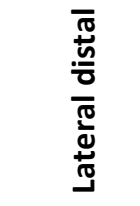 & $\begin{array}{l}\overline{\mathbb{0}} \\
\stackrel{\circ}{\circ}\end{array}$ \\
\hline AK-22 & Type 1 & $3(75 \%)$ & $1(25 \%)$ & 0 & 0 & 0 & 0 & 0 & $4(100 \%)$ \\
\hline AK-22 & Type 2 & 0 & $1(25 \%)$ & $2(50 \%)$ & 0 & 0 & $1(25 \%)$ & 1 & $5(100 \%)$ \\
\hline AK-22 & Type 1-2 & 0 & $5(62 \%)$ & 0 & 0 & 0 & $3(38 \%)$ & 0 & $8(100 \%)$ \\
\hline AK-40 & Type 1 & $5(62 \%)$ & $2(25 \%)$ & 0 & 0 & 0 & 0 & $1(13 \%)$ & $8(100 \%)$ \\
\hline AK-40 & Type 2 & 0 & 10 (59\%) & 0 & 0 & 0 & 0 & $7(41 \%)$ & 17 (100\%) \\
\hline AK-40 & Type 1-2 & 0 & 2 (100\%) & 0 & 0 & 0 & 0 & 0 & $2(100 \%)$ \\
\hline AK-43 & Type 1 & $6(33 \%)$ & $4(22 \%)$ & 0 & 0 & $1(6 \%)$ & $2(11 \%)$ & $5(28 \%)$ & $18(100 \%)$ \\
\hline AK-43 & Type 2 & 0 & $2(10 \%)$ & $6(32 \%)$ & $2(11 \%)$ & 0 & $9(47 \%)$ & 0 & $19(100 \%)$ \\
\hline AK-43 & Type 1-2 & 0 & $10(48 \%)$ & 0 & 0 & 0 & $8(38 \%)$ & $3(14 \%)$ & $21(100 \%)$ \\
\hline Total & & 14 & 37 & 8 & 2 & 1 & 23 & 17 & \\
\hline
\end{tabular}

Table 4. Al-Kharj samples MDRC and DPA.

\begin{tabular}{|c|c|c|c|c|c|c|c|c|c|}
\hline$\stackrel{ \pm}{*}$ & 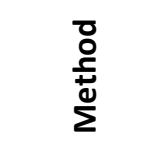 & 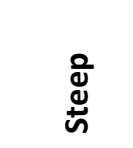 & 宓 & $\frac{\frac{0}{\frac{\sigma}{0}}}{\frac{0}{0}}$ & $\begin{array}{l}\overline{\widetilde{J}} \\
\text { ठ․ }\end{array}$ & 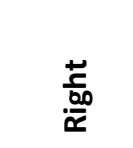 & 窇 & 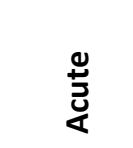 & $\begin{array}{l}\text { N } \\
\text { సే } \\
\stackrel{0}{0}\end{array}$ \\
\hline AK-22 & Type 1 & 0 & $3(75 \%)$ & $1(25 \%)$ & $4(100 \%)$ & $2(50 \%)$ & 0 & $2(50 \%)$ & $4(100 \%)$ \\
\hline AK-22 & Type 2 & 0 & $1(25 \%)$ & $3(75 \%)$ & $4(100 \%)$ & 0 & $3(75 \%)$ & $1(25 \%)$ & $4(100 \%)$ \\
\hline AK-22 & Type 1-2 & $1(12 \%)$ & $2(25 \%)$ & $5(63 \%)$ & $8(100 \%)$ & $1(12 \%)$ & $4(50 \%)$ & $3(38 \%)$ & $8(100 \%)$ \\
\hline AK- 40 & Type 1 & $6(67 \%)$ & $2(22 \%)$ & 1 (11\%) & $9(100 \%)$ & $3(33 \%)$ & $5(56 \%)$ & $1(11 \%)$ & $9(100 \%)$ \\
\hline AK- 40 & Type 2 & $9(60 \%)$ & $4(27 \%)$ & $2(13 \%)$ & $15(100 \%)$ & $5(33 \%)$ & $6(40 \%)$ & $4(27 \%)$ & 15 (100\%) \\
\hline AK-40 & Type 1-2 & 0 & $2(100 \%)$ & 0 & $2(100 \%)$ & 0 & 0 & 0 & 0 \\
\hline AK-43 & Type 1 & $5(28 \%)$ & $950 \%)$ & $4(22 \%)$ & $18(100 \%)$ & $6(35 \%)$ & 11 (65\%) & 0 & 17 (100\%) \\
\hline AK-43 & Type 2 & $4(21 \%)$ & $9(47 \%)$ & $6(32 \%)$ & $19(100 \%)$ & $3(16 \%)$ & $8(42 \%)$ & $8(42 \%)$ & $19(100 \%)$ \\
\hline AK-43 & Type 1-2 & $5(24 \%)$ & $9(43 \%)$ & 7 (33\%) & 21 (100\%) & $7(33 \%)$ & $8(38 \%)$ & $6(29 \%)$ & 21 (100\%) \\
\hline Total & & 30 & 41 & 29 & & 27 & 45 & 25 & \\
\hline
\end{tabular}


In Figure 8, the metric data for all Nubian cores (including Type 1, 2 and 1-2) is presented. Nubian cores from AK-43 are more elongated, thicker, and have greater volumes than the other Al-Kharj samples, followed by AK-22. Cores at AK-22 are the shortest with the lowest average ICE and with high average ICF, indicating that most of the cores are wide and thick. The AK-40 cores show the lowest average volume from the all the analysed samples (Figure 8). Cores are flat and thin, averaging $63.11 \mathrm{~mm}$ in length, are more elongated that the AK-22 cores, and are closer in their proportions to the ICE and ICF values of AK-43.
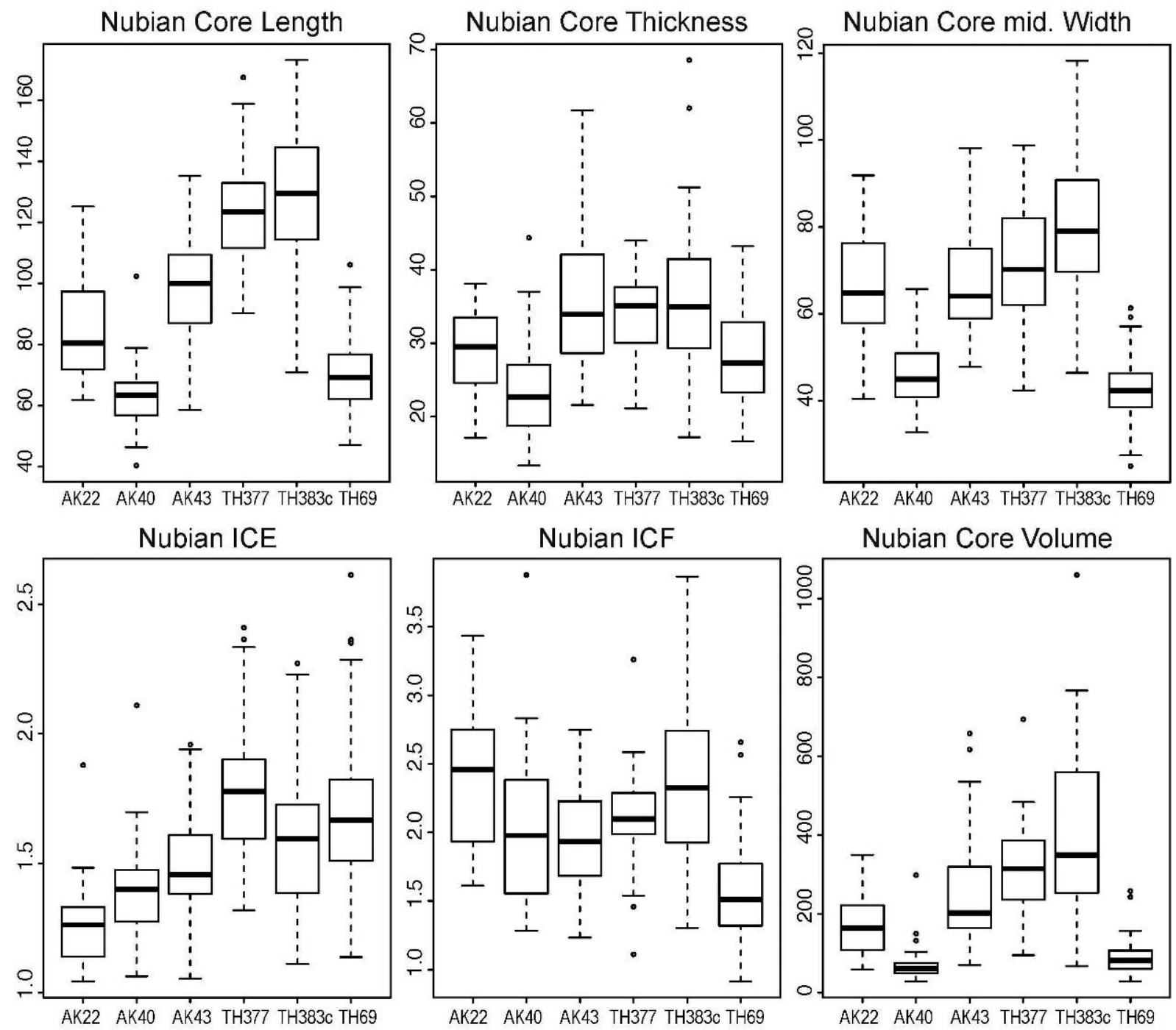

Figure 8. Metric analysis of the Nubian cores from Al-Kharj (Saudi Arabia) and Dhofar (Oman).

\subsection{Dhofar samples}

The Dhofar NC assemblages from TH.69 (Aybut ath Thani), TH.377, and TH.383 (Jebel Markhashik) are fully described in Rose et al. (2011) and Usik et al. (2013). A brief overview of the sites' location, raw material availability, and assemblage composition is given here and will serve as the basis for the comparison with the Al-Kharj samples. TH.69 is located approximately five kilometers north of the modern village of Mudayy, situated on a plateau between Wadi Aybut and Wadi Mudayy. The lithic scatter is located approximately 250 meters away from the nearest Mudayy chert outcrop, no naturally occurring raw material was found directly on the site. TH.377 is located some seven kilometers east of Mudayy village, on a plateau between Wadi Amawt and Wadi Banawt. The site is found on a Mudayy chert 
outcrop and the lithic scatter is of moderate density (5 to 10 artifacts per square meter). TH.383 is located at the foot of a low jebel, also on the Amawt-Banawt plateau some $2.5 \mathrm{~km}$ south of TH.377. The site is located directly on a Mudayy chert outcrop and has a high density of Middle Paleolithic Nubian cores. Based on the 1206 artifacts analyzed from these three assemblages, it is clear that Nubian Levallois technology is more frequent than at the Al-Kharj sites (Table 5).

Table 5. Artifact counts from TH.69, TH.377 and TH.383.

\begin{tabular}{lccc}
\hline Artifact type & TH.69 & TH.377 & TH.383c \\
\hline Non-Levallois cores & $\mathbf{1 4}$ & $\mathbf{0}$ & $\mathbf{4 7}$ \\
\hline Single platform unidirectional & 5 & 2 & 17 \\
Bidirectional opposed & 3 & 3 & 12 \\
Radial & 0 & 2 & 1 \\
Bidirectional crossed & 0 & 1 & 0 \\
Pre-core & 0 & 1 & 3 \\
Core fragment & 6 & 1 & 14 \\
\hline Levallois cores & $\mathbf{1 5 8}$ & $\mathbf{3 5}$ & $\mathbf{6 8}$ \\
\hline Nubian Type 1 & 47 & 13 & 29 \\
Nubian Type 2 & 13 & 9 & 4 \\
Nubian Type 1-2 & 42 & 9 & 17 \\
Early stage or undetermined & 53 & 4 & 15 \\
Indeterminate Levallois & 0 & 0 & 2 \\
Centripetal Levallois & 3 & 0 & 1 \\
\hline Debitage & $\mathbf{2 1}$ & $\mathbf{1 3 1}$ & $\mathbf{7 2 2}$ \\
\hline Blade & - & 30 & 113 \\
Cortical elements & - & 17 & 194 \\
Flake & - & 64 & 361 \\
\hline Levallois flake & - & 17 & 20 \\
Nubian Levallois point & 21 & 3 & 34 \\
Total & $\mathbf{1 9 3}$ & $\mathbf{1 7 6}$ & $\mathbf{8 3 7}$ \\
\hline
\end{tabular}

In general, Dhofar Nubian sites are characterized by the high percentage of Nubian cores in relation to other Levallois methods. The frequency of Type 1 Nubian Levallois is high: of the 183 Nubian cores analyzed, 49\% are attributed to this type. Type 2 are rarer, making up $14 \%$ of the sample, while Type $1-2$ comprise the remaining $37 \%$. In Table 6 , the predominance of cores with bidirectional and bidirectional laterally prepared Levallois surfaces is apparent. Bilateral, lateral distal, and bilateral preparation methods are also observed, predominantly on Type 2 and Type 1-2 prepared cores. In terms of core shapes (Table 7), triangular variants are more frequent than pitched and cordiform. At TH.69, all shapes are represented in approximately similar proportions (Figure 9), whereas only three specimens are pitched in the TH.377 assemblage. Nubian cores from TH.69, TH.377 and TH.383 show specific tendencies in respect to MDR and DPA. Oblique MDRs are rare in all samples, steep terminations being more common than semi-steep (Table 8). DPAs are generally acute (46\%) and semi-acute (37\%), only a small number of cores from TH.69, TH.377 and TH.383 showed right distal platform angles (17\%). 
Table 6. Dhofar samples Levallois surface preparation.

\begin{tabular}{|c|c|c|c|c|c|c|c|c|}
\hline 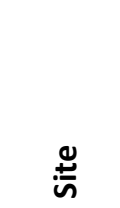 & 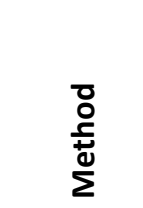 & 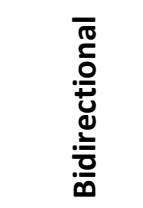 & 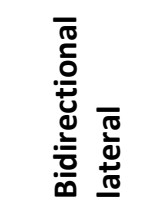 & $\begin{array}{l}\bar{\pi} \\
\frac{\pi}{ \pm} \\
\frac{\pi}{\infty} \\
\frac{\pi}{\infty}\end{array}$ & 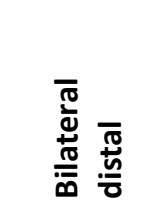 & $\begin{array}{l}\bar{\pi} \\
\frac{\Delta}{0} \\
\frac{\pi}{0} \\
\frac{\pi}{0} \\
\frac{\pi}{0}\end{array}$ & 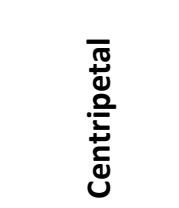 & 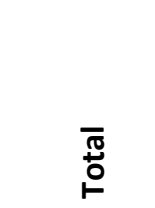 \\
\hline \multirow[t]{3}{*}{ TH.69 } & Type 1 & 39 (83\%) & $8(17 \%)$ & 0 & 0 & 0 & 0 & $47(100 \%)$ \\
\hline & Type 2 & 0 & 0 & 0 & $5(38,5 \%)$ & $5(38,5 \%)$ & $3(23 \%)$ & $13(100 \%)$ \\
\hline & Type 1-2 & $5(12 \%)$ & 35 (83\%) & 0 & 0 & 0 & $2(5 \%)$ & 42 (100\%) \\
\hline \multirow[t]{3}{*}{ TH.377 } & Type 1 & $5(46 \%)$ & $4(36 \%)$ & 0 & $2(18 \%)$ & 0 & 0 & 11 (100\%) \\
\hline & Type 2 & 0 & 0 & $3(60 \%)$ & 0 & 0 & $2(40 \%)$ & $5(100 \%)$ \\
\hline & Type 1-2 & 0 & $3(60 \%)$ & $1(20 \%)$ & $1(20 \%)$ & 0 & 0 & $5(100 \%)$ \\
\hline \multirow[t]{3}{*}{ TH.383 } & Type 1 & 19 (61\%) & 9 (29\%) & 0 & 0 & $3(10 \%)$ & 0 & 31 (100\%) \\
\hline & Type 2 & 0 & 0 & $1(20 \%)$ & $4(80 \%)$ & 0 & 0 & $5(100 \%)$ \\
\hline & Type 1-2 & 0 & $8(42 \%)$ & $2(10,66 \%)$ & $5(26 \%)$ & $2(10,66 \%)$ & $2(10,66 \%)$ & 19 (100\%) \\
\hline Total & & 68 & 67 & 7 & 17 & 10 & 9 & \\
\hline
\end{tabular}

Table 7. Dhofar samples core shape.

\begin{tabular}{lccccc}
\hline Site & Method & Triangular & Pitched & Cordiform & Total \\
\hline TH.69 & Type 1 & $15(35 \%)$ & $12(28 \%)$ & $16(37 \%)$ & $43(100 \%)$ \\
& Type 2 & $6(46 \%)$ & $4(31 \%)$ & $3(23 \%)$ & $13(100 \%)$ \\
& Type 1-2 & $13(35 \%)$ & $15(41 \%)$ & $9(24 \%)$ & $37(100 \%)$ \\
TH.377 & Type 1 & $8(73 \%)$ & $3(27 \%)$ & 0 & $11(100 \%)$ \\
& Type 2 & $360 \%)$ & 0 & $2(40 \%)$ & $5(100 \%)$ \\
& Type 1-2 & $360 \%)$ & 0 & $2(40 \%)$ & $5(100 \%)$ \\
TH.383 & Type 1 & $16(55 \%)$ & $7(24 \%)$ & $6(21 \%)$ & $29(100 \%)$ \\
& Type 2 & $2(50 \%)$ & $1(25 \%)$ & $1(25 \%)$ & $4(100 \%)$ \\
& Type 1-2 & $6(43 \%)$ & $5(36 \%)$ & $3(21 \%)$ & $14(100 \%)$ \\
\hline Total & \multicolumn{7}{c}{$\mathbf{7 2}$} & $\mathbf{4 7}$ & $\mathbf{4 2}$ & \\
\hline
\end{tabular}

Table 8. MDR cross sections and DPA (Dhofar samples).

\begin{tabular}{|c|c|c|c|c|c|c|c|c|c|}
\hline \multirow[b]{2}{*}{ Site } & \multicolumn{5}{|c|}{ MDRCS } & \multicolumn{3}{|c|}{ DPA } & \multirow[b]{2}{*}{$\begin{array}{l}\text { Total } 2 \\
(100 \%)\end{array}$} \\
\hline & Method & Steep & $\begin{array}{l}\text { Semi- } \\
\text { steep }\end{array}$ & Oblique & $\begin{array}{l}\text { Total } \\
(100 \%)\end{array}$ & Right & $\begin{array}{l}\text { Semi- } \\
\text { acute }\end{array}$ & Acute & \\
\hline \multirow[t]{3}{*}{ TH.69 } & Type 1 & 17 (40\%) & $23(53 \%)$ & $3(7 \%)$ & 43 & $\begin{array}{c}11 \\
(25 \%)\end{array}$ & $\begin{array}{c}20 \\
(45 \%)\end{array}$ & $13(30 \%)$ & 44 \\
\hline & Type 2 & $6(55 \%)$ & $4(36 \%)$ & 1 (9\%) & 11 & 4 (31\%) & $2(15 \%)$ & 7 (54\%) & 13 \\
\hline & Type 1-2 & $14(38 \%)$ & $20(54 \%)$ & $3(8 \%)$ & 37 & $4(10 \%)$ & 16 (39\%) & 21 (51\%) & 41 \\
\hline \multirow[t]{3}{*}{ TH.377 } & Type 1 & $8(80 \%)$ & $2(20 \%)$ & 0 & 10 & $3(27 \%)$ & $4(36,5 \%)$ & $4(36,5 \%)$ & 11 \\
\hline & Type 2 & 3 (75\%) & $1(25 \%)$ & 0 & 4 & 2 (50\%) & $1(25 \%)$ & $1(25 \%)$ & 4 \\
\hline & Type 1-2 & 2 (67\%) & $1(33 \%)$ & 0 & 3 & 0 & 2 (50\%) & 2 (50\%) & 4 \\
\hline \multirow[t]{3}{*}{ ТН.383 } & Type 1 & 18 (69\%) & 7 (27\%) & $1(4 \%)$ & 26 & 1 (5\%) & $10(53 \%)$ & $8(42 \%)$ & 19 \\
\hline & Type 2 & $3(100 \%)$ & 0 & 0 & 3 & 0 & 0 & 2 (100\%) & 2 \\
\hline & Type 1-2 & $7(54 \%)$ & $6(46 \%)$ & 0 & 13 & 0 & $3(27 \%)$ & $8(73 \%)$ & 11 \\
\hline Total & & 78 & 64 & 8 & & 25 & 54 & 66 & \\
\hline
\end{tabular}



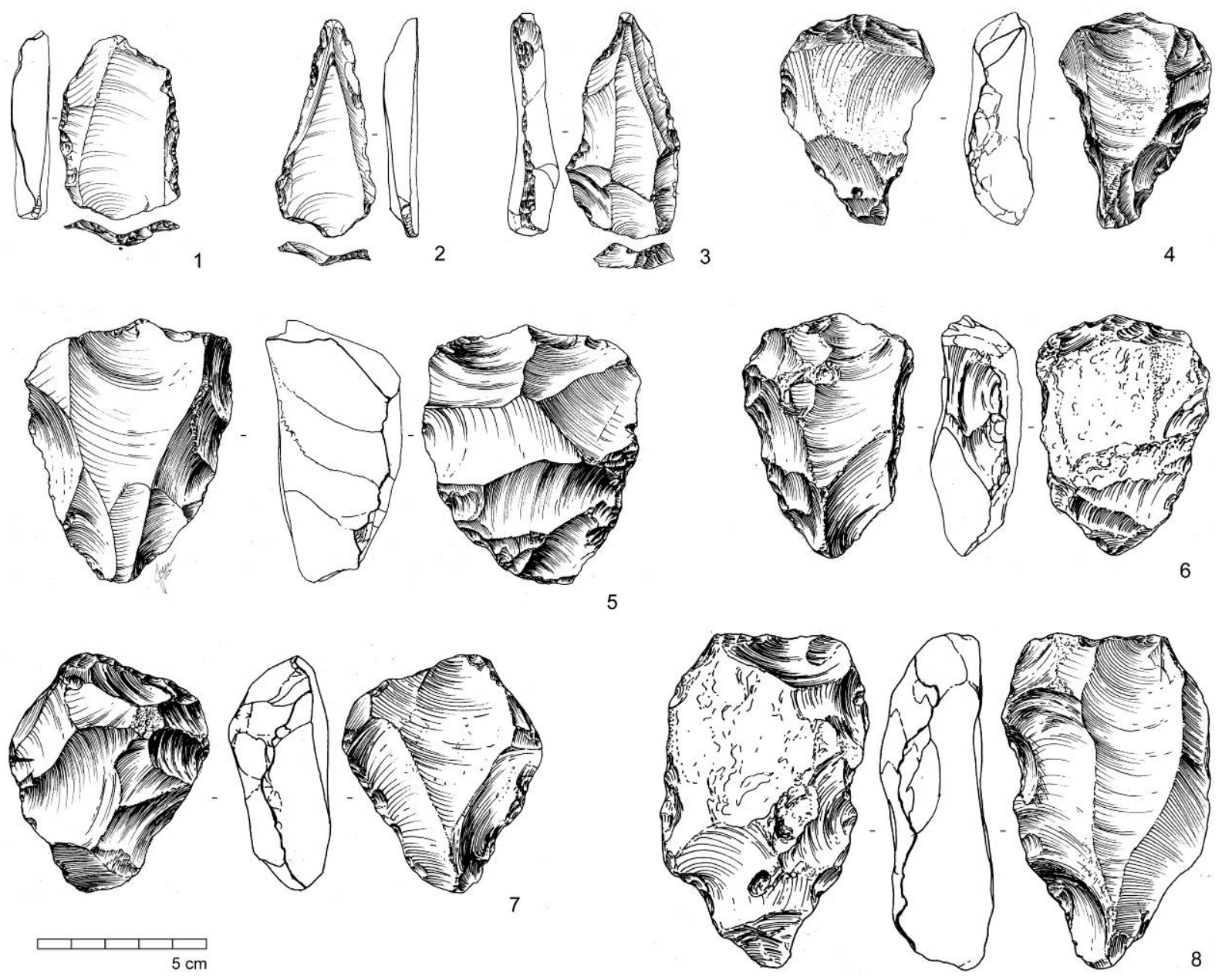

Figure 9. Nubian cores from TH.69 Dhofar. 1: Levallois flake; 2 and 3: Nubian points; 4: triangular core with Type 2 Nubian preparation; 5: cordiform core with Type 2 Nubian preparation; 6: pitched core with Type 1-2 Nubian core preparation; 7: cordiform core with Type 1 Nubian preparation; 8: pitched core with Type 1 Nubian preparation.

Nubian cores from Dhofar show some variability in metric range between sites (Figure 8). Nubian cores from TH.377 show the highest ICE within the sample and are more elongated than the cores from the other sites. The samples form TH.383 are the largest and have the highest core volume, they are the second most elongated and show high ICF values indicating that they are wide relative to their thickness. Cores from TH.69 are different; showing the lowest volume and the lowest ICF values indicating that there are thick and narrow. They are short, showing the lowest length average, and are also relatively thin. One of the patterns identified by Usik et al. (2013) regarding artifact size was that cores from sites located directly on raw material outcrops are larger than those from sites more than $250 \mathrm{~m}$ from raw material sources. This pattern is apparent Figure 8, which shows core volumes from TH.69, located about $500 \mathrm{~m}$ from a raw material outcrop, as significantly lower than the core volumes from TH.377 and TH.383, located directly on raw material outcrops.

\section{Results}

This section presents the results obtained from the comparison of the Dhofar and AlKharj Nubian core samples. The Nubian Levallois cores from the Arabian NC sites of TH.69, TH.377, TH.383, AK-22, AK-40 and AK-43 were compared in terms of their technological attributes and metric parameters. These two groups were manufactured on different raw materials and are geographically over $1000 \mathrm{~km}$ apart from one another. The assemblages from 
Dhofar were made on chert while the Al-Kharj cores were made on quartzite. In spite of these differences, Nubian Levallois cores in both regions show comparable traits. Scar patterns on the dorsal face of Nubian cores exhibit variable use of convexity preparation methods. Bidirectional. Bidirectional and bidirectional-crossed preparation are most common among all samples from both groups. Lateral. Lateral distal, bilateral, and bilateral distal scar patterns occur at all sites except AK-40. Centripetal preparation is rare and appears sporadically in the sample at AK-43, TH.69, TH.377 and TH.383. TH.69 and AK-40 show the lowest amount of variability in dorsal preparation. Nubian cores show a concise distribution of shapes, with triangular forms being predominant. AK-43 and TH.69 have similar distributions of core shape, while at the remaining sites triangular shapes are more numerous than pitched and cordiform. Right, semi-acute and acute DPAs are similarly distributed among the sites save TH.383 in Dhofar, which showed a lack of right DPAs. MDR cross-sections are somewhat variable, at AK-43 and TH.69 cores have similar proportions of steep, semi-steep and oblique cross sections (in both cases semi-steep MDR cross-sections prevail over the other variations). Based on this study, no regional pattering can be observed. Techno-typological analysis indicates that different raw materials used in assemblages more than $1000 \mathrm{~km}$ had little effect on the application of Nubian technology. It seems the Nubian Levallois template was harder than stone.

Metric results show that there is a strong correlation between core sizes and the distance from the raw material outcrop, a trend observed in both regions. Quantitatively, the samples from AK-40 and TH.69 have, on average, smaller cores than at AK-22, AK-43, TH.377 and TH.383. This might be explained by the absence of locally available raw material, corroborating the observation that proximity to raw material affects core size. It must be noted, however, that raw material outcrops are virtually ubiquitous in the area around Mudayy, making it difficult to locate lithic scatters more than $250 \mathrm{~m}$ from an outcrop. The standardization in dorsal preparations seen at AK-40 and TH.69 is possibly related to the advanced stage in core reduction, when a focus on bidirectional and bidirectional crossed preparation types may be expected. Sites located away from raw material sources are more likely to have cores in later stages of reduction, consequently with lower volumes. Henry (1989) demonstrates a "distance-decay" relationship for lithic sites in areas away from raw material sources. This pattern was previously noted, among others, by Munday (1976) and Marks (1988), where the authors correlated a decrease in core volume and blank size at Middle Paleolithic sites in the central Negev desert with their respective distance to raw material outcrops. Similarly, Beck et al. (2002), working in the North American Great Basin, quantitatively demonstrate that the production stage of bifacial manufacture advances the further they are found from raw material outcrops. It is evident that cores from Al-Kharj and Dhofar located away from raw material sources are smaller than cores found at outcrops. Consequently, more sites and additional research is needed to articulate the effect of outcrop distance on Nubian Levallois core metric variability.

The sites located on raw material outcrops, TH.383, TH.377, AK-43 and AK-22, show variable metric patterns (Figure 8). Cores from Dhofar have greater volumes than cores from Al-Kharj. Furthermore, the cores from Al-Kharj are not as elongated as the cores from Dhofar, which have high ICE values. Regardless of the difference in core volume at AK-40 and AK-43, these specimens show comparable ICE and ICF values, AK-43 being slightly more elongated that AK-40. This pattern indicates that at both sites, comparable proportioned Nubian points have been made. The cores from AK-22, on the other hand, are much shorter and wider, indicating that Nubian cores at AK-22 were used to produce shorter Nubian points. In Dhofar, cores from TH.383 show similar proportions to the cores from Al-Kharj, having the lowest ICE values from the Dhofar sample. Moreover, the cores are relatively wide and flat, according to the high ICF value, which is only slightly lower than the average ICF for 
AK-22. TH.383 Nubian cores, however, are larger than the cores from other sites. TH.377 and TH.69 have high ICE values while TH.377 shows high and TH.69 low ICF average values, indicating that TH.69 cores are proportionally narrower and thicker than other cores for either Al-Kharj or Dhofar. TH.377 cores are the most elongated with the highest ICE values.

For our analysis, a normal distribution within the spread of measured values and indices was assumed, though only TH.377 confirmed this statistically in all data when verified with the Shapiro-Wilk test. In Dhofar, the TH.383c values also show a normal distribution except for core volume. In comparison, TH.69 core volumes differ significantly from a normal distribution, while the values length, ICE and ICF are also not normally distributed. Only the ICE of cores in AK-22 site in the Al-Kharj region represent values where our assumption is significantly rejected. The two other sites, however, show a highly significant non-normal distribution in core volumes, which are accompanied with a parametric variation in midpoint width and thickness or a non-parametric one in midpoint width for AK-40 or AK-43 respectively.

While core size is linked to the size of the raw material available at each of the sites, the proportions of the cores, as reflected by ICE and ICF values, are more likely to reflect, on a basic scale, human technological behavior as opposed to raw material constraints associated with the use of chert or quartzite. Specific characteristics associated with raw material constraints, which have been observed on the Nubian cores from central and southern Arabia, can be traced back to particular fracturing and knapping mistakes. A property of the quartzite assemblages from Al-Kharj, central Saudi Arabia, is that the Nubian cores are particularly prone to some knapping fractures. These are, as previously discussed in section 2.2, hinge fracturing of the preferential removal, the overpassing (or plunging) of the preferential removal and siret fractures (Figure 10). These knapping mistakes and fractures may occur at different stages during the manufacture of preferential products while using the Levallois reduction method. Generally these are observed during dorsal surface preparation, platform preparation and when the preferential blank is extracted. At AK-22 three Nubian cores exhibited hinged preferential removals and two had siret fractures. AK-40 has the highest percentage of unsuccessful Nubian cores: ten with hinged preferential negatives, five with overpassed negatives and three with siret fractured preferential negatives. At AK-43 four hinged, five overpassed and three siret fractures have been observed on the preferential negative on the Nubian cores. Both, hinge fracturing and overpassing have also been observed on Nubian cores from Dhofar, southern Oman and are not unique to a specific type of raw material (Rose et al. 2011). At TH.377 and at TH.383, hinge fractured preferential negatives have been observed on, respectively five and one Nubian cores. Overpassing of the preferential removal is common at all sites, TH.69, TH.377 and TH.383 (respectively $n=1$, $n=2$ and $n=5$ ). Siret fractures, on the other hand, have not been observed at these sites. This type of fracture is not common amongst Dhofar assemblages and has been only sporadically observed. In some cases, hinge fractured preferential removals led to the abandonment of the core, in other cases, as seen at AK-40 and AK-43 (Figure 10, 1 and 3), attempts to rejuvenate the dorsal surface have been made (in most cases unsuccessfully). Overpassing of the preferential removal generally led to the abandonment of the core at the analyzed sites. One core from AK-43 (Figure 10, 13), however, shows a successive attempt to further use the volume and convexity of the core, resulting in the extraction of a rectangular flake.

Based on preliminary knapping experiments focusing on the implementation of the Nubian reduction method on quartzite from the Al-Kharj area, we observed that a considerable amount of force and precision is needed to perform this technique, not to mention skill and a profound understanding of mechanical fracture dynamics. The chert from Dhofar, on the other hand, requires less force to process, however, requires just as much understanding of knapping angles and fracture mechanics as any other knappable raw 
material. The frequent knapping accidents and mistakes occurring at Al-Kharj are likely the result of raw material specific properties of the quartzite. We argue that these properties, however, had no influence on Nubian Levallois technology itself.

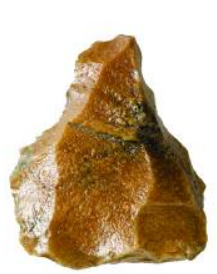

1

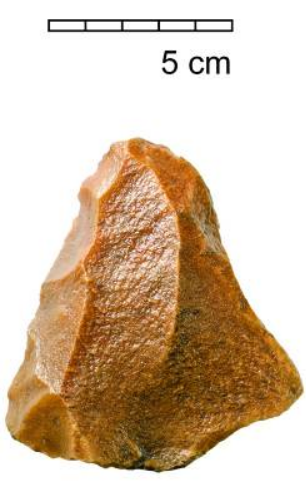

6

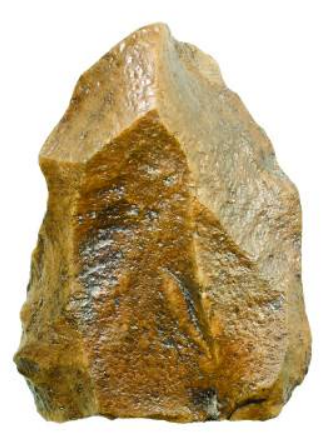

7

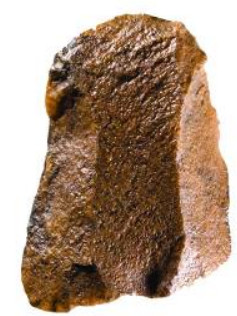

11
10

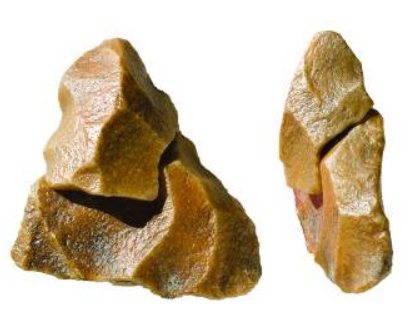

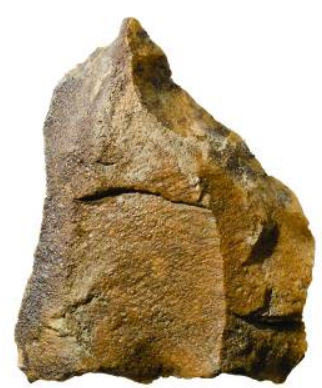

3
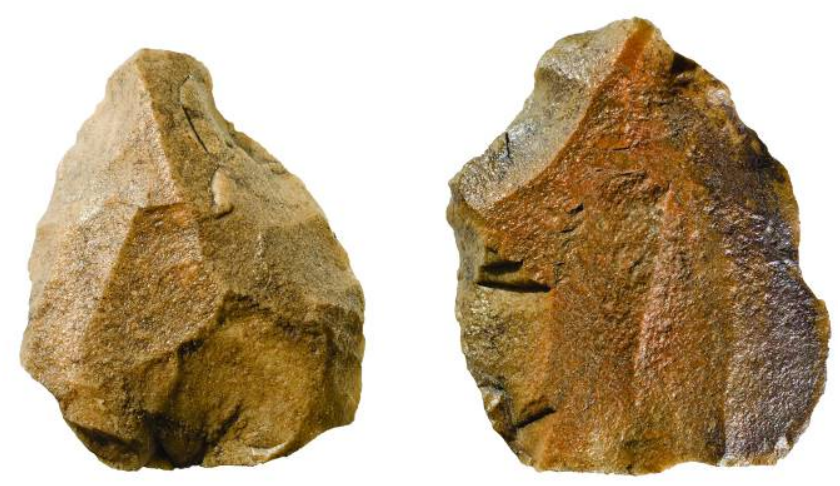

8

9

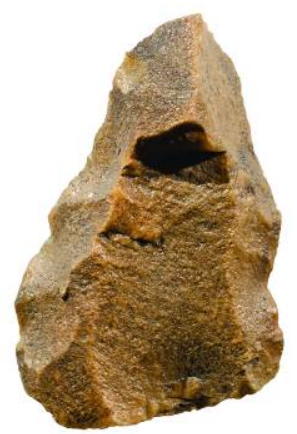

5

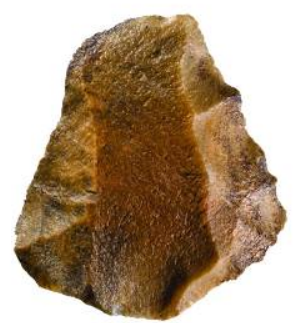

12

Figure 10. Cores from Al-Kharj showing knapping mistakes. 1 to 2 (AK-40) and 3 to 5 (AK-43): cores showing a failed preferential removal doe to hinge fracture; 6 to 9 (AK-43): cores showing a failed preferential removal due to siret fracture; 10 (AK-40): refitting of core with overshot preferential removal; 11 to 13 (AK-43): cores with plunging (overpassed) preferential removal.

\section{Discussion}

The results of this analysis of Nubian cores from Al-Kharj and Dhofar indicate that the cores from each assemblage present a set of specific technological patterns that fall with the Nubian Levallois spectrum. Some may be related to raw material size, the availability of raw material at the site or regionally specific cultural constraints. To better understand and interpret Nubian core variability between sites from different areas, it is helpful to review the concept of a "contextual area". The contextual area, or eco-cultural niche, is understood as the conceptualization of cultural similarities and differences found at sites, which cover a wide spatial and temporal spectrum (Richter et al. 2012). By analyzing the recurrent association of similar cultural items and traits across time and space, archaeologists are able to address them 
as cohesive adaptive systems, which can be defined as a cultural entity with specific traits that are shared between people across time (d'Errico \& Banks 2013). Contextual areas may move, expand and contract, as well as undergo restructuring of some of the diagnostic features. d'Errico and Banks (2013) discuss how the mechanisms behind Middle Paleolithic or Middle Stone Age cultural trajectories may transpire, proposing that climate change or stability may foster or inhibit change within a cohesive adaptive system. From this perspective change can, but does not always occur. Archaeologically this would be expressed in four different ways: 1) continuity between the material cultures across time, 2) continuity with change, when the material culture of the cohesive adaptive system is changed and restructures, retaining its original function and its key recognizable features, for, for instance when the same reduction method is applied to produce differently proportioned end products, 3) archaeological invisibility, in which populations responsible for the material culture are no longer present in the area, and 4) cultural differences, when the material cultures at two points in time are characterized by different elements.

Northeast Africa and the Arabian Peninsula might then appear to have shared a contextual area that included Nubian Levallois technology as one of its cultural traits during MIS 5. Cores from Dhofar and Al-Kharj are technologically similar, while exhibiting specific dimensional morphologies. Could the fact that Dhofar cores are larger and more elongated than Al-Kharj cores be related to local raw material constraints? At AK-43 cores are much larger that at AK-22, the quartzite outcrops are more extensive at AK-43 than at AK-22. Similarly, at TH.383 and TH.377 nodule size may have played a role in final core volume. The size of the cores at the moment of their disposal, however, provides only limited information on the dimension of the unworked piece of raw material. Unfortunately, there are no metric data for the unworked chert nodules from Dhofar or the quartzite slabs from AlKharj, making it difficult to test the effect of raw material size on core size. The high ICE values for the Dhofar Nubian cores, on the other hand, likely reflects the choice of the artisans to produce elongated end products using Nubian Levallois strategy rather that raw material constrains. If we translate this into the contextual area model, this pattern could be explained by a combination of possible scenarios. Nubian technology may have been used to produce slightly less elongated end products in northeast Africa and central Saudi Arabia, while the Dhofar Nubian cores are more elongated showing that continuity with change in this area occurred. An indication for this would be to test if the ICE values for the Dhofar Nubian core samples correspond to a normal distribution, which would indicate that a specific outcome was being attempted (Table 9). At both TH.383 and TH.69, the ICE valued do not correspond to a normal distribution, which may be due to higher values from more elongated outliers. If less elongated outliers or a bimodal distribution is detected, this would mean that two different preferential outcomes were sought, one more elongated that the other. TH.69 represents a special case given the metric and proportional differences from both Al-Kharj and Dhofar samples, indicating additional local variability in Dhofar among NC sites. This could be linked with the distance to raw material source, or could indicate that Dhofar presents a specific developmental trajectory as previously argued by some (Usik et al. 2013; Rose \& Marks 2014). This could serve as indication that Dhofar Nubian technology was brought to South Arabian and further developed locally in Dhofar, undergoing change while retaining its key technological characteristic. An alternative scenario might envision the already modified, more elongated, Nubian technology was brought to Dhofar from a different area. All of these scenarios, however, remain speculative without further chronological resolution. Data presented by Rose and Marks (2014) indicate, based on Index of Elongation, that Nubian assemblages from Dhofar are more elongated that their northeastern African counterparts, supporting the notion that Dhofar Nubian technology represents a local variant. Evidently, the application of the contextual area and cohesive adaptive systems based 
scenarios to the Arabian Nubian cores hinges on some of the shortcomings inherited by the data and analytical methods. One of the problems comparing NC lithic assemblages is that we are currently unable to articulate its regional chronology, other than a rough estimate based on the age of the Aybut al-Auwal sediments (Rose et al. 2011) and the age of the NC in northeast Africa - widely between 160 to 60 ka (e.g., Van Peer \& Vermeersch 2007; Van Peer et al. 2010)

Table 9: Results show the p-values (Shapiro-Wilk test) with a level of significance of $\mathrm{p}<0.05$ (indicated in red) for rejecting the assumption of a normal distribution for each site and measured value or index.

\begin{tabular}{lllllll}
\hline Site & TH383c & TH377 & TH69 & AK22 & AK40 & AK43 \\
\hline Length & 0.7817 & 0.3009 & 0.0098 & 0.3391 & 0.0297 & 0.9562 \\
mid p Width & 0.5124 & 0.5683 & 0.7489 & 0.8073 & 0.4956 & 0.0364 \\
Thickness & 0.071 & 0.8689 & 0.0916 & 0.7094 & 0.0504 & 0.0647 \\
ICE & 0.0927 & 0.2892 & 0.0258 & 0.0112 & 0.0141 & 0.0827 \\
ICF & 0.3935 & 0.0778 & 0.0063 & 0.1686 & 0.0094 & 0.3925 \\
Core Volume & 0.0399 & 0.1363 & $<0.001$ & 0.3254 & $<0.001$ & $<0.001$ \\
\hline
\end{tabular}

Our study shows that it is possible to possible to grasp some variability between Arabian NC sites. Evidence indicates that the distance from the site to a raw material source affects core volume. Cores from Dhofar are more elongated that those from Al-Kharj, which may have had some effect on the general proportions of the preferential end product. Both AlKharj and Dhofar samples clearly belong to the same technocomplex and indicate the two regions belong to a culturally-related Middle Paleolithic contextual area.

\section{Conclusion}

We have compared the NC Levallois production method from two different areas of Arabia that are more than $1000 \mathrm{~km}$ away from each other and were produced on different raw materials. No clear technological differences related to the raw material source could be ascertained. We conclude that Nubian Levallois reduction at both Dhofar and Al-Kharj sites employed the same technological process to produce a pointed preferential end product, have specific shapes that vary by site, exhibit DPA's and MDR cross-section that fall within overlapping ranges, and show predominantly bidirectional preparation of the dorsal surface of the cores. Each of the sites exhibit specific combinations for preparation of the cores, while showing comparable shape tendencies within the previously defined Nubian range. In terms of size, cores from Al-Kharj are smaller and less elongated as the cores from Dhofar; hence, a difference in the proportion of the Levallois products. While the type of raw material did affect the way that Nubian Levallois reduction methods were performed, knapping accidents occur more often on quartzite than on chert based assemblages. The three main fracture types identified, hinge, overpassing and siret fracture, occur in both chert and quartzite-based assemblages, while siret fractures are more common in quartzite-based assemblages. Such knapping mistakes and accidents are by no means restricted to these two materials. The null hypothesis - that we would observe different techno-typological patterns between the two areas, and by extension different responses to raw material types - cannot be verified. Once additional Nubian sites across Arabia are found, dated and analyzed, we may be able to better understand what factors drove technological homogeneity and heterogeneity within the NC, be they chronological, biological, geographic, or cultural in nature. 


\section{Acknowledgments}

We are grateful to the organizers of the $10^{\text {th }}$ International Symposium on Knappable Materials held at the University of Barcelona in September 2015. The fieldwork in Dhofar was financed by the AHRC and National Geographic Waitt grant, both awarded to JR and held under the auspice of the Ministry of Heritage and Culture of Oman. Fieldwork in AlKharj was funded by the Saudi Commission for Tourism and National Heritage and the French Ministry of Foreign Affairs. RC and YHH a grateful to Jérémie Schiettecatte for his support and bonne humeur as co-director of the Archaeological Mission in Al-Kharj. The authors are grateful to the anonymous reviewers of this paper for their time and input.

\section{References}

Amirkhanov, H.I. 2006, Каменный век Южной Аравии. Nauka, Moscow, 632 p. (in Russian) ("Stone Age in South Arabia”)

Armitage, S.J., Jasim, S.A., Marks, A.E., Parker, A.G., Usik, V.I. \& Uerpmann, H.P. 2011, The southern route "Out of Africa": Evidence for an early expansion of modern humans into Arabia. Science, 331: 453-456. doi:10.1126/science.1199113

Bailey, G.N. 2009, The Red Sea, coastal landscapes and hominin dispersals. In: The evolution of human populations in Arabia: Paleoenvironments, Prehistory, and Genetics (Petraglia, M.D.\& Rose, J.I. Eds.), Springer Academic Publishers, Netherlands, p. 1537. doi:10.1007/978-90-481-2719-1_2

Beck, C., Taylor, A.K., Jones, G.T., Fadem, C.M., Cook, C.R., \& Millward, S.A. 2002, Rocks are heavy: transport costs and paleoarchaic quarry behavior in the Great Basin. Journal of Anthropological Archaeology, 21: 481-507. doi:10.1016/s0278-4165(02)00007-7

Best, M.G. 1982, Igneous and Metamorphous Petrology. W.H. Freeman, San Francisco, $630 \mathrm{p}$.

Blinkhorn, J., Achyuthan, H. \& Ajithprasad, P. 2015, Middle Paleolithic point technologies in the Thar Desert, India. Quaternary International, 382: 237-249.

doi:10.1016/j.quaint.2015.02.027

Boëda, E., Bourguignon, L. \& Griggo, C. 1998, Activités de subsistance au Paléolithique moyen: Couche VI3 b’ du gisement d'Umm El Tlel (Syrie). In: Économie préhistorique: Les stratégies de subsistance au Paléolithique. 18e Rencontres Internationales d'Histoire et d'Archéologie d'Antibes (Brugal, J.P., Meignen, L. \& Patou-Mathis, M. Eds.), Editions APDCA, Sophia-Antipolis: p. 243-258. (in French) ("Subsistence activities during the Middel Paleolithic: Level VI3 B from the site Umm El Tlel”)

Boutié, P. \& Rosen, S.A. 1989. Des gisements moustériens dans le Néguev central. Résultats préliminaires de prospections récentes. In: Investigations in South Levantine Prehistory / Préhistoire du Sud-Levant (Bar-Yosef, O., Vandermeersch., B. Eds.), BAR International Series Vol. 497, Archaeopress, Oxford: p. 147-166. (in French) ("Mousterian sites in the Central Negev. Preliminary results of recent investigations")

Chiotti, L., Dibble, H.L., Olszewski, D.I., McPherron, S.R. \& Schurmans, U. 2009, Middle Paleolithic Lithic Technology from the Western High Desert of Egypt. Journal of Field Archaeology, 34: 307-318.

Clark, J.D. 1988, Middle Stone Age of East Africa and the beginnings of regional identity. Journal of World Prehistory, 2: 235-305. doi:10.1007/bf00975618 
Crassard, R. 2009, Middle Paleolithic in Arabia: The view from the Hadramawt region, Yemen. In: The Evolution of Human Populations in Arabia. Paleoenvironments, Prehistory and Genetics (Petraglia, M.D., \& Rose, J.I., Eds.), Springer Academic Publishers, Dordrecht: p. 151-168. doi:10.1007/978-90-481-2719-1_12

Crassard, R., \& Hilbert, Y.H. 2013, A Nubian Complex site from central Arabia: Implications for Levallois taxonomy and human dispersals during the Upper Pleistocene. PLoS ONE, 8: e69221. doi:10.1371/journal.pone.0069221

Crassard, R., \& Thiébaut, C. 2011, Levallois points production from eastern Yemen and some comparisons with assemblages from East-Africa, Europe and the Levant. In: The Lower and Middle Palaeolithic in the Middle East and neighboring regions (Le Tensorer, J.M., Jagher, R., \& Otte, M., Eds.), Études et Recherches Archéologiques de l'Université de Liège (ERAUL), Liège: p. 131-142.

Delagnes, A., Tribolo,C., Bertran, P., Brenet, M., Crassard, R., Jaubert, J., Khalidi. L., Mercier, N., Nomade, S., Peigné, S., Sitzia L, Tournepiche, J-F., Al-Halibi, M., AlMosabi, A. \& Macchiarelli, R. 2012, The Middle Paleolithic assemblage of Shi'bat Dihya 1 (Wadi Surdud site complex, Yemen). Journal of Human Evolution, 63(3): 452474.

Delagnes, A., Crassard, R., Beltran, P. \& Stizia, L., 2013, Cultural and human dynamics in southern Arabia at the end of the Middle Paleolithic. Quaternary International, 300: 234-243. doi:10.1016/j.quaint.2012.12.012

Dibble, H. L., \& Whittaker, J. 1981, New experimental evidence on the relation between percussion flaking and flake variation. Journal of Archaeological Science, 6: 283-296. doi:10.1016/0305-4403(81)90004-2

d'Errico, F. \& Banks, W.E., 2013, Identifying Mechanisms behind Middle Paleolithic and Middle Stone Age Cultural Trajectories. Current Anthropology, 54(8): 371-387. doi:10.1086/673388

Goder-Goldberger, M., Gudenko, N. \& Hovers, E. 2016, “Diffusion with modifications”: Nubian assemblages in the central Negev highlands of Israel and their implications for Middle Paleolithic inter-regional interactions. Quaternary International, 408: 121-139. doi:10.1016/j.quaint.2016.02.008

Hahn, J. 1991, Erkennen und bestimmen von stein und knochenartefakten: Einführung in die Artefaktmorphologie. Archaeologica Venatoria Vol. 10, Verlag Archaeologica Venatoria, Tübingen, 314 p. (in German) (“Identification and translation of stone and bone tools: An introduction to artefact morphology")

Henry, D.O. 1989, Correlation between reduction strategies and settlement patterns. Archeological Papers of the American Anthropological Association, 1(1), 139-155.

Hilbert, Y.H., Crassard, R., Charloux, G., \& Loreto, R. in press, Nubian technology in northern Arabia: Impact on interregional variability of Middle Paleolithic industries. Quaternary International. (Available online 20 December 2015) doi:10.1016/j.quaint.2015.11.047

Inizan, M.-L. \& Ortlieb, L. 1987, Préhistoire dans la région de Shabwa au Yémen du Sud (R.D.P. Yémen). Paléorient, 13(1): 5-22. (in French) ("Prehistory in the Shabwa region of Southern Yemen”) doi:10.3406/paleo.1987.4414 
Inizan, M.-L., Reduron, M., Roche, H., \& Tixier, J. 1995, Technologie de la pierre taillée. Préhistoire de la pierre taillée, Tome 4. Cercle de Recherches et d'Études Préhistoriques (CREP), Meudon, 199 p. (in French) ("Technology of knapped stone”)

Kurashina, H. 1978, An Examination of Prehistoric Lithic Technology in East-Central Ethiopia. Ph.D. dissertation. University of California, Berkeley, 676 p.

Luedke, B. 1992, An Archaeologist's guide to chert and flint. Institute of Archaeology, University of California, Los Angeles, 172 p.

Marks A. 1988, The curation of stone tools during the Upper Pleistocene: A view from the Central Negev, Israel. In: Upper Pleistocene Prehistory of Western Eurasia (Dibble, H., \& Montet-White, A., Eds.), University Museum Press, Philadelphia: p. 87-94.

Michelsen, H. 1966, The structure of dark flint from Stevns, Denmark. Mineralogical and Geological Institute of the University of Copenhagen, Copenhagen, $14 \mathrm{p}$.

Müller, S., \& Warth, M. 1985, Kieselsäure-Wanderung in südwestdeutschen Sedimenten und die Bildung lokaler Silexwerkstoffe der Seitzeitkulturen. Archeologisscher Verein Mitteilungsblatt, 9: 4-23. (in German) (" Siliceousoxide migration in southern German sediments and the formation of local flint raw materials of stone age cultures”)

Munday, F. 1976, Intersite Variability in the Mousterian occupation of the Advat/Aqev Area. In: Prehistory and Paleoenvironment in the Central Negev, Israel (Marks, A.E., Ed.), Southern Methodist University Press, Dallas: p. 113-140.

Olszewski, D.I., Dibble, H.L., McPherron, S.P., Schurmans, U., Chiotti, L. \& Smith, J. 2010, Nubian Complex Strategies in the Egyptian High Desert. Journal of Human Evolution, 59: 188-201. doi:10.1016/j.jhevol.2010.06.001

Petraglia, M.D., 2011. Trailblazers across Arabia. Nature, 470: 50-51. doi:10.1038/470050a

Petraglia, M.D., Alsharekh, A., Breeze, P., Clarkson, C., Crassard, R., Drake, N.A., Groucutt, H.S., Jennings, R., Parker, A.G., Parton, A., Roberts, R.G., Shipton, C., Matheson, C., al-Omari, A. \& Veall, M.A., 2012, Hominin Dispersal into the Nefud Desert and Middle Palaeolithic Settlement along the Jubbah Palaeolake, Northern Arabia. PLoS ONE, 7(1) e49840. doi:10.1371/journal.pone.0049840

Platel, J.P., Roger, J., Peters, T.J., Mercolli, I., Kramers, J.D., \& Le Métour, J. 1992, Geological Map of Salalah, Explanatory Notes. Ministry of Petroleum and Minerals, Muscat.

Powers, R.W., Ramirez, L.F., Redmond, C.D., \& Elberg, E.L. 1966, Geology of the Arabian Peninsula. Geological Survey Professional Paper, 560: 1-147.

Richter, J., Hauck, T., Vogelsang, R., Widlok, T., Le Tensorer, J.-M. \& Schmid, P., 2012, Contextual areas" of early Homo sapiens and their significance for human dispersal from Africa into Eurasia between $200 \mathrm{ka}$ and $70 \mathrm{ka}$. Quaternary International, 274: 524. doi:10.1016/j.quaint.2012.04.017

Rose, J.I. \& Hilbert, Y.H. 2014, New prehistoric sites in the southern Rub’ al-Khali desert, Oman. Antiquity: Project Gallery, 88.

URL: http://journal.antiquity.ac.uk/projgall/rose341

Rose, J.I. \& Marks, A.E. 2014, “Out of Arabia” and the Middle-Upper Palaeolithic transition in the southern Levant. Quartär, 61: 49-85. doi:10.7485/QU61_03 
Rose, J.I. \& Petraglia M.D. 2009, Tracking the Origin and Evolution of Human Populations in Arabia. In: The Evolution of Human Populations in Arabia. Paleoenvironments, Prehistory and Genetics (Petraglia, M.D., \& Rose, J.I., Eds.), Springer Academic Publishers, Dordrecht: p. 1-12.

Rose, J.I., Usik, V.I., Marks, A.E., Hilbert, Y.H., Galletti, C.S., Parton, A., Geiling, J.M., Černý, V., Morley, M.W., \& Roberts, R.G. 2011, The Nubian Complex of Dhofar, Oman: An African Middle Stone Age Industry in Southern Arabia. PLoS ONE, 6(11): e28239. doi:10.1371/journal.pone.0028239

Rottländer, R.C.A. 1989, Verwiterungs erscheinungen an Silices und Knochen. Verwitterungserscheinungen an Keramik, Silices und Knochen Vol. 2, Tübinger Beiträge zur Archäometrie Vol. 3, Archeologica Venatoria, Tübingen, 176 p. (in German) ("Deterioration phenomena on flint and ceramics. Deterioration of ceramics, flints and bones")

Schiettecatte, J., al-Ghazzi, A., Charloux, G., Crassard, R., Hilbert, Y.H., Monchot, H., Mouton, M., \& Siméon, P. 2013, Al-Kharj oasis through time: First results of archaeological fieldwork in the province of Riyadh (Saudi Arabia). Proceedings of the Seminar for Arabian Studies, 43: 285-308.

Tryon, C.A. \& Faith, J.T. 2013, Variability in the Middle Stone Age of Eastern Africa. Current Anthropology, 54(8): 234-254. doi:10.1086/673752

Usik, V.I., Rose, J.I., Hilbert, Y.H., Van Peer, P., \& Marks, A.E. 2013, Nubian Complex reduction strategies in Dhofar, southern Oman. Quaternary International, 300: 244-266. doi:10.1016/j.quaint.2012.08.2111

Van Peer, P. \& Vermeersch, P.M. 2000, The Nubian Complex and the dispersal of modern humans in North Africa. In: Recent research into the Stone Age of northeastern Africa (Krzyzaniak, L., Kroeper, K., Kobusiewicz, M. Eds.), Poznan Archaeological Museum, Poznan: p. 47-60.

Van Peer, P., \& Vermeersch, P.M. 2007, The place of northeast Africa in the early history of modern humans: New data and interpretations on the Middle Stone Age. In: Rethinking the Human Revolution (Mellars, P., Boyle, K., Bar-Yosef, O., \& Stringer, C., Eds.), McDonald Institute for Archaeological Research, Cambridge: p. 187-198.

Van Peer, P., Vermeersch, P.M., \& Paulissen, E. 2010, Chert Quarrying, Lithic Technology and a Modern Human Burial at the Palaeolithic Site of Taramsa 1, Upper Egypt. Leuven University Press, Leuven, 312 p.

Vaslet, D., Al-Muallem, M.S., Maddah, S.S., Brosse, J.-M., Fourniguet, J., Breton, J.-P., \& Le Nindre, Y.-M. 1991, Explanatory notes to the geologic map of the Ar Riyad Quadrangle, Kingdom of Saudi Arabia. Geoscience map GM-121, scale 1:250,000, sheet 24I. Deputy Ministry for Mineral Resources, Ministry of Petroleum and Mineral Resources, Kingdom of Saudi Arabia, Jeddah. 54 p.

Whittaker, J. 1994, Flintknapping: Making \& Understanding Stone Tools. University of Texas Press, Austin, 352 p.

Will, M., Mackay, A. \& Phillips, N. 2015, Implications of Nubian-Like Core Reduction Systems in Southern Africa for the Identification of Early Modern Human Dispersals. PLoS ONE, 10(6): e0131824. doi:10.1371/journal.pone.0131824 
Yellen, J., Brooks, A., Helgren, D., Tappen, M., Ambrose, S., Bonnefille, R., Feathers, J., Goodfriend, G., Ludwig, K., Renne, P. \& Stewart, K. 2005, The archaeology of Aduma Middle Stone Age sites in the Awash Valley, Ethiopia. Paleoanthropology, 10: 25-100.

Zarins, J. 2001, The Land of Incense: Archaeological work in the Governorate of Dhofar, Sultanate of Oman, 1990-1995. Archaeology \& cultural heritage series, v. 1 Archaeology \& Cultural Heritage Series Vol. 1, Sultan Qaboos University Publications, Muscat, $192 \mathrm{p}$. 